\title{
Elvis Orbanić
}

Zavod za povijesne i društvene znanosti HAZU u Rijeci, Područna jedinica u Puli

Prolaz kod kazališta 2, HR-52100 Pula

eorbanic@hazu.hr

\section{„Čovjek koji je početkom 18. stoljeća pobožno živio". Prinos biografiji Petra Antuna Gausa (1646. - 1716.), pićanskoga biskupa"}

\author{
Izvorni znanstveni rad | Original scientific paper \\ UDK 929Gaus, A.G.:27-722.52](497.571-21Pićan)"17" \\ DOI 10.32728/h2020.02 \\ Primljeno | Received: 23. VI. 2020.
}

\section{Izvadak}

Članak donosi pregled života i djelovanja pićanskoga biskupa Petra Antuna Gausa, kao i njegove obitelji u Rijeci na temelju dosadašnje historiografske literature, objavljenih i neobjavljenih vrela. Od neobjavljenih vrela s ciljem upotpunjavana mozaika poznavanja života toga prelata Katoličke crkve raščlanjena je njegova oporuka i kodicil, kroničarski zapisi anonimnoga autora iz Pićna, Težakova kronika s početka 19. st., matične knjige krštenih, vjenčanih i umrlih Rijeke (17. i 18. st.) i matična knjiga krštenih, vjenčanih i umrlih Pićna te matična knjiga krštenih Gračišća. Ukazano je i na gradivo koje dosad nije obrađivano u Vatikanskom apostolskom arhivu. Od objavljenih izvora korištena je Knjiga ređenja u Pićnu, Popis dobara Pićanskoga kaptola iz 1746. te u opsežnim sažetcima objavljene relacije ad limina. Razdoblje Gausova upravljanja Pićanskom biskupijom dijelom je predstavljeno usporedbom s onima drugih biskupa toga mjesta. Kao dodatak članku donosi se prijepis dosad neobjavljene Gausove oporuke i kodicila.

\section{Excerpt}

The article offers an overview of the life and work of the Bishop of Pićan, Peter Anton Gaus, as well as his family in Rijeka, based on previous historiographical literature, published and unpublished sources. Using unpublished sources with the goal of completing the mosaic of the knowledge about the life of this prelate of the Catholic Church, his will and codicil, chronicle records of an anonymous author from Pićan, Težak's chronicle from the beginning of the $19^{\text {th }}$ century, registers of baptisms, marriages and deaths in Rijeka ( $17^{\text {th }}$ and $18^{\text {th }}$ centuries), as well as the registry of baptized, married and deceased in Pićan and the registry of baptized in Gračišće, have been examined. The material that has not so far been processed in the

* I would like to acknowledge the ERC-AdriArchCult GA n. 86586, which has received funding from the European Union's Horizon 2020 Research and Innovation Programme. 


\begin{abstract}
Vatican Apostolic Archive has also been shown. Of the published sources, the Book of Ordinations in Pićan, the List of Goods of the Pićan Chapter from 1746 and the ad limina published in extensive summaries were used. The period of Gaus' rule of the Diocese of Pićan is partly represented by a comparison with that of other bishops of that place. In addition to the article, a transcript of the so far unpublished Gaus' will and codicil are provided.
\end{abstract}

Ključne riječi: Petar Antun Gaus, Pićanska biskupija, Istra, Rijeka, rani novi vijek, pobožnost, oporuka

Key words: Peter Anton Gaus, Pićan Diocese, Istria, Rijeka, Early Modern Period, piety, the last will and testament

\title{
Uvod: poticajni događaj
}

Kolovoških dana 1811. Pićanci su imali prilike doživjeti nesvakidašnji prizor. Župna crkva Navještenja Blažene Djevice Marije bila je tih ljetnih dana u cjelini pobijeljena, svetište popločeno kamenim pločama, popravljena sjedišta te su napravljene nove kamene stube uspona na orgulje. Popravljen je i biskupski tron, iako biskupa u Pićnu nije bilo više od četvrt stoljeća. Tijekom tih radova i obnove unutar župne crkve nasljednici pićanskoga biskupa Bonifacija Cecottija (1697. - 1765. $)^{1}$ dali su podići grobnicu ispred oltara svetoga Ivana, smještenoga pokraj Svetoga groba, s namjerom da ga ondje premjeste iz zajedničke grobnice pićanskih biskupa koja se nalazila u svetištu. Treba napomenuti da zajednička grobnica nije bila otvarana pola stoljeća. Prilikom radova na premještanju tijela pokojnoga biskupa u novu grobnicu otvorena je ta zajednička grobnica, no odmah je zatvorena jer su pronašli jedno neraspadnuto tijelo.

Do pićanskoga župnika i dekana Ivana Antuna Težaka (1776. - 1836.) došla je obavijest o namjeri otvaranja biskupske grobnice unutar svetišta pa je sazvao sav pićanski kler, koji se sastojao od pet klerika, a među njima je bio i kanonik Lukež. Župnik je, okružen pićanskim klerom, dao zatvoriti vrata crkve s ciljem nastavka započetoga prijenosa zemnih ostataka, no vodeći računa o pijetetu prema pokojnicima. Tako je otvorena grobnica u kojoj je uočeno neraspadnuto tijelo jednoga biskupa koje je svojom veličinom prelazilo grobno mjesto pa su mu koljena bila savijena, a učinilo im se da mu je i glava odvojena od tijela. Očevici su opazili da mu je na koljenima i nogama vidljiva

1 O Bonifaciju Cecottiju vidi: Ivan Grah, „Izvještaji pićanskih biskupa Svetoj Stolici (1589-1780““ (dalje: „Izvještaji pićanskih biskupa“), Croatica Christiana periodica, 6, 1980., 12 i literatura u bilješci 46. 
koža. Biskupsko znakovlje je također bilo jasno vidljivo na tom truplu, kao i cendali te cipele s crveno-bijelim petama.

Tom neobičnom i vjerski snažnom doživljaju nije tu bio kraj. Zbog nepažnje zidara, pokrov lijesa je svom silinom pao na skvrčena pokojnikova koljena, a da ih nije značajnije oštetio.

Otad pa do dovršetka popločenja crkve neraspadnuto je tijelo danima bilo predmetom promatranja znatiželjnih mještana. Sukladno tradiciji zapisanoj u župnoj kronici s početka 19. stoljeća, tijelo je pripadalo pokojnom pićanskom biskupu Gausu, čovjeku „koji je početkom 18. stoljeća pobožno živio“.2

\section{Obiteljske prilike}

Premda nam ostaje nepoznat točan nadnevak rođenja, znamo da je Petar Antun Gaus (Petrus Antonius Gaus) kršten 9. siječnja 1646. ${ }^{3}$ u Rijeci po rukama prezbitera Valerijana Tremaninija ${ }^{4}$ u obitelji Marka Antuna i Sidonije Gaus. Njegov će sakrament kršćanske inicijacije sagledan iz očišta društvenoga događanja poduprijeti ugledni kum iz Rijeke. Bila je to najviđenija osoba iz laičkoga javnog života toga kvarnerskoga grada: Ferdinand slobodni barun à Ruvere, ${ }^{5}$ inače gradski kapetan, a uz njega i Katarina, supruga Askanija Giacominija ${ }^{6}$ Iako se u nekim historiografskim radovima uz toga prelata spominje i ime Paulus, ${ }^{7}$ treba istaknuti da u zapisu krštenja u matičnoj knjizi krštenih Rijeke nema toga imena, baš kao ni u njegovoj oporuci i dvije godine

2 (...) quanto dalla Tradizione combinar si poteva, dirsi deve quel corpo essere il defunto Vescovo Gauss di Pedena, Uomo quale nel principio del Seccolo 1700- mille settecento piamente viveva. (Župni ured Pićan, Satutus animarum župe Pićan iz 1807. godine, 5,2; rukopis: Memoria rellativa all'Imperiale Parrochia decanale di Pedena cominciata scrivere con la possibile accuratezz a nel Luglio dell Anno mille ottocento dodici / 1812./ da Giovanni Antonio Tesach, str. 2-3.) Taj je rukopis u obliku župne kronike u postupku objave. Priređivači su Jakov Jelinčić i Elvis Orbanić.

3 HR-DARI-0275, Matična knjiga krštenih Rijeka (1635. - 1674.), knjiga 417, 9. siječnja 1646. Na prostoru Porečke biskupije, prema biskupskoj sinodi iz 1675., krštenje je trebalo obaviti unutar osam dana od rođenja. Giuseppe Cuscito, „Sinodi e riforma cattolica nella diocesi di Parenzo“, poseban otisak iz Atti e memorie della Società istriana di archeologia e storia patria, 75, 1975., 67. Praksa na primjeru župe Pazin je pokazala da se krštenje dijelilo u većini slučajeva unutar toga roka. No, u 33,6 \% slučajeva je prelazilo rok od osam dana. Elvis Orbanić, Društveni i religiozni život Porečke biskupije „a parte Imperij“ u 17. stoljeću. Primjer Pazina, Starog Pazina, Svetog Petra u Šumi i Žminja, doktorska disertacija, Sveučilište u Zagrebu 2012., 75.

4 Obitelj Tremanini je u Rijeci zabilježena od druge polovice 16. st. Giovanni Kobler, Memorie per la storia della liburnica città di Fiume (dalje: Memorie), volume III, 1-a ristampa, Fiume - Trieste 1978., 188.

5 Ferdinando barone della Rovere je bio riječki kapetan od 1639. do smrti 1672. Isti, Memorie II, 179.

6 HR-DARI-0275, Matična knjiga krštenih Rijeka (1635. - 1674.), knjiga 417, 67. Giacomini su bili riječka obitelj od 16. st. nadalje. Isti, Memorie III, 164.

7 Tako Kandler piše Pietro Antonio Paolo Gauss (Pietro Kandler, Pel fausto ingresso di monsignore D. Bartolomeo Legat vescovo di Trieste e Capodistria nella sua chiesa di Trieste [dalje: Pel fausto ingresso], Trieste 1847.) i Pietro A. Paolo Gauss, Fium. (Pietro Kandler, Indicazioni per riconoscere le cose storice del Litorale [dalje: Indicazioni], Trieste 1855., 129). Camillo De Franceschi također rabi i ime Paolo (Camillo De Franceschi, „Storia documentata della Contea di Pisino“ [dalje: „Storia documentata“], Atti e memorie della Società istriana di archeologia e storia patria, n. s., 10-11, 1964., 342). 
kasnijem kodicilu. Što se tiče pisanja njegova prezimena, u svim je pregledanim zapisima u matičnim knjigama beziznimno napisano u obliku Gaus (a ne Gauss).

Riječki će povjesnik Kobler napisati za obitelj Gaus da se prvi put pojavljuje u Rijeci 1616., i to kao bračni par Petar i Ana. Petar Gaus je sukladno carskim diplomama iz 1614. i 1630. bio plemić nasljednih austrijskih zemalja i Svetoga Rimskog Carstva Njemačke Narodnosti. ${ }^{8}$ Izdanke te obitelji u Rijeci nalazimo s prezimenskim dodatkom koji odražava njihov plemićki status, a bilježen je na različite načine: de Hahnberg, ${ }^{9}$ d'Homberg, ${ }^{10}$ d'$^{\prime} /$ de Omperg, ${ }^{11}$ à Homperg, ${ }^{12}$ de Homperg, ${ }^{13}$ ab Homperg. ${ }^{14}$ Petar i Ana Gaus bili su djed i baka budućega pićanskog biskupa. Naime, njihov sin Marko Antun i supruga Sidonija imat će trojicu sinova: Petra Antuna, Ivana Karla i Nikolu Martina. ${ }^{15}$

\section{a) Gausova braća i njihova djeca}

Ivan Karlo je kršten u travnju 1652., ${ }^{16}$ a vjenčao se Belonom Monaldi u studenom 1675. godine. ${ }^{17}$ Službovao je niz godina kao gradski sudac, a u braku s Belonom rodila su im se četiri sina. ${ }^{18}$

Od tih sinova riječki povjesničar Kobler je izdvojio Eustahija koji je bio kanonik u Rijeci, ${ }^{19}$ izabran na kanoničko mjesto 1712., a umro je u studenom 1762. godine. ${ }^{20}$ Petra Antuna Eustahija je u srpnju $1683 .{ }^{21} \mathrm{krstio}$ pulski biskup

8 Kobler, Memorie III, 162.

9 Isto, 163; Pietro Tomasin, Storia ecclesiastica di Trieste e dell Istria, volume II, Vescovi di Pedena e Cittanova. Rukopis pohranjen u Archivio diplomatico del Comune di Trieste.

10 Na Padovanskom sveučilištu dva su biskupova nećaka, Pietro Eustachio Gaus d Hoberg i Saverio Andrea Gaus d Homberg, navedena kao plemići s tim oblikom prezimena. Studenti istriani e fiumani all Università di Padova dal 1601 al 1974, a cura di Luciana Sitran Rea - Giuliano Piccoli, Treviso 2004., 45, 49.

11 U oporuci i kodicilu Petra Antuna Gausa, prezimenski dodatak će biti zapisan u tom obliku. Župni arhiv Pićan (dalje: ŽAP), Oporuka, 2; de Omperg (ŽAP, Kodicil A.).

12 Ivan Karlo, brat Petra Antuna Gausa, tako se bilježi (HR-DARI-0275, Matična knjiga krštenih Rijeka (1695. - 1705.), knjiga 418, 1. prosinca 1697.; isto, 5. prosinca 1697.).

13 Župni arhiv Gračišće (dalje: ŽAG), Matična knjiga krštenih Gračišće (1667. - 1745.), popis krizmanika iz 1694.

14 Ivan Karlo, brat Petra Antuna Gausa, tako je bilježen. HR-DARI-0275, Matična knjiga vjenčanih Rijeka (1706.-1720.), knjiga 419, knjiga 419, 12. veljače 1707 .

15 Kobler, Memorie III, 163.

16 HR-DARI-0275, Matična knjiga krštenih Rijeka (1635. - 1674.), knjiga 417, 28. travnja 1652.

17 HR-DARI-0275, Matična knjiga vjenčanih Rijeka (1675. - 1705.), knjiga 418, 28. studenog 1675. Obitelj Monaldi nalazimo u Rijeci od početka 17. st. Kobler, Memorie II, 172.

18 Kobler, Memorie III, 163.

19 Na ist. mj. Petar Eustahije je zabilježen kao kanonik koji je vjenčao jedan par 1713. godine. HR-DARI-0275, Matična knjiga vjenčanih Rijeka (1706. - 1720.), knjiga 419, 24. travnja 1713.

20 Riječki kanonik i povjesničar Josip Poglajen sastavljajući popis riječkih kanonika bilježi da je Eustahije umro u prosincu 1762. (Darko Deković, „Pronađen autograf Poglajenova popisa riječkih kanonika“ [dalje: „Pronađen autograf“], Croatica Christiana periodica, 13, 1984., 81), a Kobler, koji se zacijelo koristio Poglajenovim popisom (vidi: isto, 76-77), navodi za godinu njegove smrti 1792., što je očevidno lapsus calami (Kobler, Memorie III, 163). Točan nadnevak njegove smrti je 9. studenoga 1762. HR-DARI-0275, Matična knjiga umrlih Rijeka (1702. - 1765.), knjiga 475.

21 HR-DARI-0275, Matična knjiga krštenih Rijeka (1675. - 1695.), knjiga 418, 31. srpnja 1683. 
Bernardin Corniani (1664. - 1689.). ${ }^{22}$ Osim što taj podatak ukazuje na onodobni društveni ugled obitelji Gaus, upućuje nas na bitnu poveznicu Rijeke s Pulom. Naime, Rijeka je zajedno s tzv. liburnijskom Istrom bila pod svjetovnom vlašću Habsburgovaca, a pod duhovnom upravom pulskoga ordinarija - venecijanskoga podložnika. Zbog toga je pulski biskup upravljao tim teritorijem posredstvom arhiđakona, službe koju je obnašao i Petar Antun Gaus.

Drugi poznati sin Ivana Karla Gausa zvao se Ksaver Andrija (1688.). ${ }^{23}$ Po struci je bio pravnik, radio je kao gradski sudac i državni službenik, a preminuo je 1743. godine. ${ }^{24}$ Stric, riječki svećenik i kasniji pićanski biskup, osim što ga je osobno krstio, bio mu je naročito naklonjen i poslije tijekom života školujući ga ${ }^{25}$ te odredivši ga za nasljednika, između ostaloga, svih njegovih nekretnina. ${ }^{26}$

Treći poznati sin Ivana Karla Gausa i supruge mu Belone zvao se Josip Kandid Gaus (1695.). ${ }^{27}$

Biskupov brat Ivan Karlo, koji je preminuo 28. kolovoza 1710. u Rijeci ${ }^{28}$ imao je i četiri kćeri ${ }^{29}$ koje su se zvale Marija Antonija (1676.), ${ }^{30}$ Ana Sidonija (1677.), ${ }^{31}$ Elizabeta Sofija (1680.) ${ }^{32}$ i Franjica Paula (1692.). ${ }^{33}$ Elizabete, koju je i osobno krstio kao riječki župnik, stric biskup će se sjetiti poimenice i u svojoj oporuci.

Odnos između biskupa i njegova brata Ivana Karla može se ocijeniti posebno bliskim. Rječito nas na to upućuju navodi iz biskupove oporuke. Iz toga izvora najprije saznajemo da mu je posudio 300 dukata za vjenčanje kćeri Elizabete Sofije u veljači 1700. ${ }^{34}$ Nadalje, 74 škude biskup je platio Francescu Redingeru, ${ }^{35}$ kirurgu iz Rijeke, zbog bratova duga i duga njegove supruge,

22 O biskupu Cornianiju vidi: Ivan Grah, „Izvještaji pulskih biskupa Svetoj Stolici (1592-1802)“, Croatica Christiana periodica, 20, 1987., 50-51 i u bilješci 94 u navedenoj literaturi.

23 HR-DARI-0275, Matična knjiga krštenih Rijeka (1675. - 1695.), knjiga 418, 9. prosinca 1688.

24 Kobler, Memorie III, 163. Preminuo je 6. studenoga 1643. od moždanoga udara, a pokopan je kod augustinaca. HR-DARI-0275, Matična knjiga umrlih Rijeka (1702. - 1765.), knjiga 475, 6. studenoga 1743.

25 Vidi poglavlje „Školovanje obitelji Gaus“ unutar ovoga članka.

26 ŽAP, Oporuka, 5-7.

27 HR-DARI-O275, Matična knjiga krštenih Rijeka (1675. - 1695.), knjiga 418, 3. studenoga 1695.

28 HR-DARI-0275, Matična knjiga umrlih Rijeka (1702. - 1765.), knjiga 475, 63.

29 ŽAP, Oporuka, 7.

30 HR-DARI-0275, Matična knjiga krštenih Rijeka (1675. - 1695.), knjiga 418, 30. travnja 1676.

31 Isto, 21 . rujna 1677.

32 Isto, 22. listopada 1680.

33 Isto, 4. veljače 1692.

34 HR-DARI-0275, Matična knjiga vjenčanih Rijeka (1675. - 1705.), knjiga 418, 21. veljače 1700.

35 Francesco Redinger će dobiti riječko građanstvo 1714. godine. Giuseppe Viezzoli, „Contributi alla storia di Fiume nel Settecento“, Fiume. Rivista semestrale, 12/1933., 147. 
a tu je i 50 dukata što ih je platio kao dug Ivana Karla riječkome liječniku Giuseppeu Rocchiju. ${ }^{36}$ Držimo posve opravdanim zaključiti da je u pitanju bila bolest što je pogodila obitelj biskupova brata. Ivan Karlo zaduživao se i kod vjerskih ustanova. Zasad možemo samo pretpostavljati koji su bili razlozi tim i tolikim dugovima. Tako saznajemo da je 300 dukata biskup platio kapeli bratovštine Bezgrješnoga začeća u Rijeci na račun duga Ivana Karla, a tako je učinio i s iznosom od 100 kranjskih forinti sestrama redovnicama. Iako nije zabilježeno o kojim je redovnicama riječ, zacijelo se radi o benediktinkama jer su one bile jedine redovnice u Rijeci toga vremena, a posjedovale su samostan uz crkvu sv. Roka pokraj zborne crkve. ${ }^{37}$ Dodatnih 100 kranjskih forinti biskup je platio kao dug Ivana Karla Ziliju Zamarchiju iz Rijeke. Osim što mu je rješavao razna dugovanja, biskup je bratu davao i gotov novac. Zabilježio je to doduše samo u jednom slučaju u iznosu od 100 škuda. Biskup je tražio svojom oporukom da nasljednici Ivana Karla trebaju sav navedeni novac vratiti njegovu sinu dr. Ksaveru Gausu. Također, biskup je naložio da ako Ksaver Gaus ne dobije taj novac od nasljednika svojega oca, Ksaver ne smije tražiti od glavnoga nasljednika ikakva sredstva. ${ }^{38}$ Svoj je emotivni odnos s bratom Ivanom Karlom i pri kraju oporuke pojasnio biranim riječima: ,...nije uzmanjkao živom ljubavlju činiti dobro pokojnome bratu gospodinu Ivanu Karlu s pristojim iznosima i gotovim novcem iz čiste ljubavi....39

Treći sin obitelji Marka Antuna i Sidonije Gaus bio je Nikola Martin. Kršten je u Rijeci u studenom 1654., ${ }^{40}$ a postao je isusovac. ${ }^{41}$

Svu će trojicu sinova Marka Antuna i Sidonije Gaus krstiti isti riječki svećenik i kanonik Valerijan Tremanini (Valerianus Tremaninus/Tremanini). ${ }^{42}$

\section{b) Gausove sestre i njihova djeca}

Petar Antun Gaus imao je osim navedena i dosad u literaturi poznata dva brata, do ovoga istraživanja i nepoznatih šest sestara. Jedna sestra mu je bila

36 Giuseppe Rochi bio je riječki gradski liječnik od 1707. do 1717. Isto, 164.

37 O benediktinkama u Rijeci vidi: Ivan Ostojić, Benediktinci u Hrvatskoj i ostalim našim krajevima, sv. II., Tkon - Split 1964., 212-214; Kobler, Memorie I, 122-127.

38 ŽAP, Oporuka, 6-7.

39 ŽAP, Oporuka, 10.

40 HR-DARI-0275, Matična knjiga krštenih Rijeka (1635. - 1674.), knjiga 417, 12. studenoga 1654.

41 Kobler, Memorie III, 163. O isusovcu Nikoli Gausu vidi: Historia Collegii Goritiensis. Gli Annali del collegio dei gesuiti di Gorizia (1615-1772), a cura di Claudio Ferlan - Marco Plesnicar, Trento 2020., 452.

42 Valerijan Tremanini je na Poglajenovom popisu riječkih kanonika od 1636. pa do 1663. ili 1664., kada umire. Deković, „Pronađen autograf“, 84. 
Viktorija, krštena 1657. godine. ${ }^{43}$ Najprije je bila udana za Jurja de Bartholi $(1677 .)^{44}$ pa je postavši udovica stekla prezime Tudorović (Victoria Tudorovich) udavši se za Ivana Šimuna Tudorovića (Joannes Simonis Tudorovich) $1685 .{ }^{45} \mathrm{~s}$ kim je u braku imala četiri kćeri i dva sina. Ivan Šimun Tudorović je bio carskom ovlašću javni bilježnik u Rijeci. ${ }^{46}$ Sinovi su im bili Petar Antun Marijan Tudorović (1686. ${ }^{47}$ i Nikola Andrija Tudorović (1694.). ${ }^{48}$ za kojega doznajemo iz biskupove oporuke da je postao svećenik. ${ }^{49}$ Poglajenovo je mišljenje da je i kanonika Josipa Tudorovića trebalo uvrstiti u ovu obitelj jer ga navodi kao brata Nikoli Andriji, no to je upitno. ${ }^{50}$ Kao kćeri Ivana Šimuna i Viktorije Tudorović se navode Ana Viktorija (1689.), ${ }^{51}$ Rozalija Beatrica (1691.), ${ }^{52}$ Klara Sidonija (1696.) ${ }^{53}$ i Sidonija Margareta (1699.) $)^{54}$.

Ostale biskupove sestre su bile Ana Ivana (1643.), koja je bila i najstarije dijete te obitelji, ${ }^{55}$ Suzana (1649. ${ }^{56}$ udovica Spingarolli ${ }^{57}$, Katarina (1660. $)^{58}$

43 HR-DARI-0275, Matična knjiga krštenih Rijeka (1635. - 1674.), knjiga 417, 9. rujna 1657.

44 HR-DARI-0275, Matična knjiga vjenčanih Rijeka (1675. - 1705.), knjiga 418, 26. veljače 1677.

45 Svjedoci tom vjenčanju su bili njezin brat Ivan Karlo i Nikola Zanchi, sestrin suprug, a vjenčao ih je Viktorijin brat opat Gaus. Isto, 6. listopada 1685. Obitelj Tudorović zasvjedočena je u Rijeci od prve polovice 16. st. Kobler, Memorie III, 189.

46 Podatak o njegovoj službi javnoga bilježnika je iz 1678. godine. Jakov Jelinčić, Knjiga ređenja u Pićnu (Protocollum) (1632.-1783.) (dalje: Knjiga ređenja u Pićnu), Pazin 2015., 85-86.

47 Petrus Antonius Marcianus Tudorovich. HR-DARI-0275, Matična knjiga krštenih Rijeka (1675. - 1695.), knjiga 418, 16. rujna 1686 .

48 Nicolaus Andreas Tudorovich. HR-DARI-0275, Matična knjiga krštenih Rijeka (1675. - 1695.), knjiga 418, 4. siječnja 1694.

49 ŽAP, Oporuka, 4-5.

50 Deković, „Pronađen autograf“, 84. Josip Antun je kršten 24. rujna 1673. kao dijete Šimuna i Ivane (!) Tudorović. Supruga Šimuna Tudorovića se i prema osobnom krštenju zvala jedino Viktorija te je pri krštenju ostale djece njezino ime bilo zapisano isključivo kao Viktorija. Pretpostavljamo da je kanonik Josip Antun bio sin Šimuna Tudorovića i Ivane Fiornini (vidi: HR-DARI-0275, Matična knjiga vjenčanih Rijeka [1635. - 1674.], knjiga 417, 4. ožujka 1666.). Moguće je da mu je otac punim imenom bio Šimun Juraj. Naime, Šimun Juraj Tudorović je rođen 1642. u braku Ivana Pavla i Barbare Tudorović (HR-DARI-0275, Matična knjiga krštenih Rijeka [1635. - 1674.], knjiga 417, 3. prosinca 1642.). Biskup Gaus, iako u oporuci spominje kanonika Josipa Antuna Tudorovića kao jednoga od recipijenata i kao izvršitelja oporuke, ni na jednom mjestu ga ne naziva svojim nećakom. Pretpostavljamo da se Šimun Juraj preminućem Ivane Fornini, njegove prve supruge koja je bila kanonikova majka, kao udovac oženio Viktorijom Gaus. To bi mogao biti razlog povezivanja kanonika Josipa Antuna Tudorovića s biskupom Gausom.

51 HR-DARI-0275, Matična knjiga krštenih Rijeka (1675. - 1695.), knjiga 418, 6. veljače 1689.

52 Isto, 19. svibnja 1691.

53 HR-DARI-0275, Matična knjiga krštenih Rijeka (1695. - 1705.), knjiga 418, 22. kolovoza 1696.

54 Isto, 28. prosinca 1699.

55 HR-DARI-0275, Matična knjiga krštenih Rijeka (1635. - 1674.), knjiga 417, 26. rujna 1643.

56 Isto, 3. ožujka 1649.

57 Udana je u veljači 1684. za Ernesta Spingarollija. Vjenčanje je obavio opat Petar Antun Gaus. HR-DARI-0275, Matična knjiga vjenčanih Rijeka (1675. - 1705.), knjiga 418, 7. veljače 1684. Giovanni Ernesto Spingaroli je umro 1710. Kobler, Memorie III, 181.

58 Isto, 24. kolovoza 1660. 
udovica Zanchi ${ }^{59}$, Suzana Veronika (1667.) ${ }^{60}$ te Antonija (1669.) ${ }^{61}$, koja je rođena nakon očeve smrti.

Od biskupovih nećaka još se spominje i Ivan Josip de Marburg, carski savjetnik i pazinski kapetan kroz tri godine (1713. - 1715./1716.). Njega će biskup imenovati izvršiteljem svoje oporuke. ${ }^{62}$

\section{c) Stric svećenik kao krstitelj}

Povezanost unutar obitelji Gaus vidljiva je i kroz jedan od sakramenata kršćanske inicijacije. Petar Antun Gaus je kao svećenik u Rijeci krstio niz pripadnika svoje obitelji: Elizabetu Sofiju, kćer Ivana Karla Gausa i supruge Sidonije (1680.); Petra Antuna Marijana, sina Viktorije i Šimuna Tudorovića (1686.); Josipa Antuna, sina Nikole i Katarine Zanchi (1688.); ${ }^{63}$ Ksavera Andriju, sina Ivana Karla i Belone (1688.); nećakinju Anu Viktoriju, kćer Ivan Šimuna i Viktorije Tudorović (1689.); Katarinu Dariju, kćer Ernesta i Suzane Spingaroli (1689.); ;4 Rozaliju Beatricu, kćer Ivan Šimuna i Viktorije Tudorović (1691.). ${ }^{65}$ Nakon što je u Rimu dobio potvrdu za pićanskoga biskupa, u svibnju je 1693. krstio Petra Franju Jurja, sina Ernesta i sestre mu Suzane Spingaroli. ${ }^{66}$

\section{Školovanje obitelji Gaus}

O školovanju Petra Antuna Gausa iz dosadašnje literature zasigurno znamo jedino da je doktorirao teologiju. Ostali detalji su na razini više ili manje sigurnijih pretpostavki. Naime, Kandler će u svom djelu i ujedno prvom kronološko-povijesnom prikazu povijesti Pićanske biskupije napisati da je Gaus bio dottore di teologia, ${ }^{67}$ a De Franceschi ga opisuje kao laureato in teologia ${ }^{68}$. Kandlerov navod potvrđuje biskupova oporuka u kojoj je naveden kao „carski savjetnik, doktor teologije, gospodar Gologorice“. U red riječkih

59 Udana je u lipnju 1680. za Nikolu Zanchija. Vjenčanje je obavio opat Gaus. HR-DARI-0275, Matična knjiga vjenčanih Rijeka (1675. - 1705.), knjiga 418, 5. lipnja 1680. Obitelj Zanchi postoji u Rijeci od prve polovice 16. st. Kobler, Memorie III, 194.

60 HR-DARI-0275, Matična knjiga vjenčanih Rijeka (1675. - 1705.), knjiga 418, 1. veljače 1667.

61 Isto, 7. kolovoza 1669.

62 De Franceschi njegovo prezime piše u obliku Marpurg(De Franceschi, „Storia documentata“, 120, 349), a u oporuci i kodicilu je u obliku Marburg. ŽAP, Oporuka, 12., ŽAP, Kodicil, B. O riječkoj obitelji Marburg vidjeti: Kobler, Memorie II, 168.

63 HR-DARI-0275, Matična knjiga krštenih Rijeka (1675. - 1695.), knjiga 418, 8. travnja 1688.

64 Isto, 22. prosinca 1689.

65 Vidi bilj. 52.

66 HR-DARI-0275, Matična knjiga krštenih Rijeka (1675. - 1695.), knjiga 418, 4. svibnja 1693. Taj će Franjo postati isusovac. Kobler, Memorie II, 181

67 Kandler, Pel fausto ingresso.

68 De Franceschi, „Storia documentata“, 342 . 
doktora teologije 17. st. Gausa svrstava i Deković služeći se Poglajenovim popisom riječkih kanonika. ${ }^{69}$ Iako s oprezom, držimo mogućim da je temeljnu naobrazbu stekao u Rijeci kod isusovaca u njihovoj gimnaziji. ${ }^{70} \mathrm{Na}$ to nas upućuje i podatak o njegovu mlađem bratu Nikoli Martinu, koji je postao član upravo reda sv. Ignacija.

Da je obitelj Gaus držala na cijeni studiranje u poznatijim sveučilišnim gradovima, kazuje oporučna konstatacija iz koje jasno iščitavamo kako je sinove Ivana Karla Gausa upravo njegov brat i biskup Petar Antun financirao tijekom njihovih studija u inozemstvu. U tu je svrhu potrošio ukupno 1200 dukata. Jednoga je nećaka uzdržavao tri godine u Njemačkoj, a drugoga također tri godine - dvije u Gorici i jednu u Padovi. Platio je i troškove doktorata prvoga nećaka u Padovi u iznosu od 445 dukata. ${ }^{71}$ Nećak kojega je biskup školovao do doktorata u Padovi bio je Ksaver Andrija Gaus, koji je ondje studirao od 1707. do 1709. postigavši doktorat in utroque iure 18. travnja 1709. godine. ${ }^{72} \mathrm{Na}$ istome padovanskom sveučilištu pravo je studirao i Ksaverov brat Petar Eustahije nekoliko godina prije, ${ }^{73}$ a koji će - za razliku od brata - prijeći u svećenički stalež.

\section{Crkvene službe Petra Antuna Gausa}

U Rijeci je sve do 1923. bila samo jedna župa s crkvom Uznesenja Marijina kao župnom crkvom. ${ }^{74}$ U njoj su svoje sjedište imali kolegijalni kaptol s arhiđakonom na čelu te župnik. ${ }^{75}$ O Petru Antunu Gausu saznajemo - slijedeći Koblera - da je bio župnikom u Rijeci od 1678. do 1683., nakon čega je postao (riječkim) arhiđakonom pa biskupom u Pićnu. ${ }^{76}$ Prateći upise u maticu krštenih Rijeke tijekom 1678. nema sačuvanoga podatka da je Petar Antun Gaus ikoga krstio, a kao župnik se navodi Ivan (Joannes) Cal(l)i, ${ }^{77}$ dok je kao arhi-

69 Darko Deković, Istraživanja o riječkome glagoljaškom krugu, Rijeka 2011., 122-123; isti, „Pronađen autograf“, 81.

70 O osnutku i djelovanju isusovačke gimnazije u Rijeci vidi: Valentin Miklobušec, „Isusovci u Rijeci 1627.- 1773.

Školsko, pastoralno i odgojno djelovanje“, Riječki teološki časopis, 52, 2018., 187-190.

$71 \check{Z}$ AP, Oporuka, 10.

72 Sitran Rea - Piccoli, Studenti istriani e fumani, 49.

73 Isto, 45.

74 Marko Medved, Riječka Crkva u razdoblju fašizma, Zagreb 2015., 25. Iznimka je bila od 1789. do 1807., kada je u vrijeme jozefinizma postojala još jedna župa za područje zapadno od Gradske ure. Kobler, Memorie I, 81.

75 Kobler, Memorie I, 75.

76 „Pietro Antonio, parroco di Fiume dal 1678 al 1683, poi arcidiacono, indi vescovo di Pedena“. Kobler, Memorie II, 163 .

77 Ivan Andrija Calli bio je župnik primjerice tijekom 1675., kao i 1678. (3. siječnja 1678.). Njegovo prezime se također piše neujednačeno, Cali (4. ožujka 1675.) i Calli (1. srpnja 1675.). HR-DARI-0275, Matična knjiga krštenih Rijeka (1675. - 1695.), knjiga 418. 
đakon naveden Franjo Cal(l)uc(c)i(us). ${ }^{78}$ Župnik Calli je zadnji put u Rijeci krstio u travnju 1678. godine. ${ }^{79}$ Gaus će se prvi put navesti kao krstitelj, a ujedno i kao župnik Rijeke u lipnju 1679. godine. ${ }^{80}$ Iz toga proizlazi da je Gaus postao riječkim župnikom između travnja 1678. i lipnja 1679. godine. Poglajen će za početak Gausova župnikovanja uzeti 1679. godinu. ${ }^{81} \mathrm{U}$ službi župnika relativno će rijetko biti krstiteljem; tu ulogu su uglavnom obnašali riječki kanonici te arhiđakon Caluci. U zajednicu je riječkih kanonika, koji su tijekom 17. st. brojili konstantno osam članova, ${ }^{82}$ uvršten carevom potvrdom u srpnju $1679 .{ }^{83}$ te ga kao riječkoga kanonika, župnika i krstitelja nalazimo prvi put početkom lipnja 1680. godine. ${ }^{84}$ Nakon skoro godine dana, preciznije u svibnju 1681., Gaus se pojavljuje kao krstitelj na položaju riječkoga arhiprezbitera (natpopa). ${ }^{85}$ Nakon promaknuća kanonika i župnika Gausa na položaj arhiđakona 17. srpnja $1683 .^{86}$ bilo je stanovitih poteškoća s novim župnicima jer dvojica koja su mu uslijedila, Stemberg i Fiorin, tu službu nisu obnašali. Iz toga je razloga Gaus bio župnikom pro tempore od 1684. do 1688. godine. ${ }^{87}$ Gausov nasljednik na mjestu arhiprezbitera i župnika Rijeke je kanonik Petar Marija Monaldi, upisivan s tim naslovima od travnja 1688., ${ }^{88}$ a on će ga naslijediti i na položaju arhiđakona $1693 .{ }^{89}$

78 Prezime toga riječkog arhiđakona pisalo se u matici krštenih na više načina: Calucci (16. svibnja 1678.), Calucius (14. studenog 1678.), Callucius (26. studenog 1678.), Caluci (22. prosinca 1678.). Na ist. mj. Od Calucijevijh nasljednika Gaus će kupiti vinograd na području Sv. Nikole u Rijeci. ŽAP, Oporuka, 3.

79 Isto, 22. travnja 1678.

80 ...ego Petrus Antonius Gaus parochus F(lum)inis... Isto, 20. lipnja 1679.

81 U Poglajenovu popisu riječkih kanonika stoji da je Gaus postao župnikom 1679., a da se pritom ne donosi precizan nadnevak. Deković, „Pronađen autograf", 81.

82 Kobler, Memorie I, 80.

83 Prema Poglajenovu popisu riječkih kanonika ispada da je Gaus uveden u dužnost kanonika 15. studenoga 1678. a da ga je potvrdio car 17. srpnja 1679. godine. Deković, „Pronađen autograf“, 81

84 ...Petrus Antonius Gaus plebanus et canonicus...; HR-DARI-0275, Matična knjiga krštenih Rijeka (1675. 1695.), knjiga 418, 1. lipnja 1680.

85 ...Petrus Antonius Gaus Archipresbyter civitatis Fluminis...; HR-DARI-0275, Matična knjiga krštenih Rijeka (1675. - 1695.), knjiga 418, 22. svibnja 1681. Tu će godinu kao početak službe Gausova arhiprezbiterata donijeti i Poglajen. Deković, „Pronađen autograf“, 81.

86 Naslijedit će te godine preminuloga arhiđakona Franju Calucija. Giuseppe Poglayen, „Memorie cronologiche relative alle chiese e al capitolo di Fiume“ (dalje: „Memorie cronologiche“), Fiume, 8/1930, 1931., 125.

87 Na ist. mj.; Deković, „Pronađen autograf", $81,86$.

88 Per promotione(m) in Archidiaconatu(m) R(everendissi)mi Abbatis Gaus, ego Petrus Maria Monaldus Can(onic) us loco suprad(ict)i fui electus in Arhip(resbyter)um et Parochu(m). Upis nije datiran, a nalazi se neposredno iznad nadnevka jednoga krštenja 1. travnja 1688. Monaldi je kao krstitelj prvi put zabilježan naslovom arhiprezbitera i župnika 18. travnja 1688. HR-DARI-0275, Matična knjiga krštenih Rijeka (1675. - 1695.), knjiga 418. I u matici vjenčanih je sadržajno jednak zapis između 2. veljače i 3. svibnja 1788. bez nadnevka HR-DARI-0275, Matična knjiga vjenčanih Rijeka (1675.-1705.), knjiga 418. Iz toga proizlazi da je do formalnoga preuzimanja službe došlo tijekom veljače ili ožujka 1688.

89 Kobler, Memorie I, 78. 
U upisima u maticu krštenih Rijeke Gaus će biti zabilježen u studenom 1684. prvi put kao arhiđakon i vanjski vikar. ${ }^{90}$

Ostaje otvorenim pitanje trajanja njegova župnikovanja u Bolzanu u Južnom Tirolu, gdje je, prema pisanju De Franceschija, Gaus službovao do povratka u Rijeku. ${ }^{91}$

Naslov opata (abbas) će uz njegovo ime učestalo stajati od siječnja 1684. na stranicama matice krštenih. Kandler i De Franceschi će napisati da je Gaus bio opat Sv. Jurja u Canalu. ${ }^{92}$ Podatak o Gausovu položaju opata Sv. Jurja u Canatu donosi nam navod u biskupovoj oporuci i dvije godine kasnijem kodicilu. Jednako je tako i u knjizi ređenja Pićanske biskupije naveden kao abbas Sancti Georgi in Canat. ${ }^{93}$ Poglajen pak navodi da je Gaus bio „opat mitronosac“ Liča u Gorskome kotaru i da je kao takav zabilježen $1688 .^{94}$

Gaus je krstio stanovitu Luciju, koju je od Turaka otkupio ${ }^{95}$ zacijelo suprug njegove sestre Viktorije, Ivan Šimun Tudorović, a bilo je to krajem prosinca 1691. te je tom prigodom u matici krštenih naveden kao electus Episcopus Petinentis. ${ }^{96}$ Gausovo zadnje krštenje u Rijeci prije rimske potvrde za biskupa bilo je u veljači 1693., kada je zapisan kao Archid(iaconus) nec non electus Episcopus Petinensis. Bilo je to dijete Tome i Apolonije Mulčić, a kumovi su na krštenju bili iz obitelji Gaus: Ernest Spingaroli, tj. suprug krstiteljeve sestre te Katarina, krstiteljeva sestra. ${ }^{97}$ Nakon što ga je car Leopold I. (1640. - 1705.) imenovao pićanskim biskupom, Petar Antun Gaus je u Rimu potvr-

90 D(ominus) Petrus Antonius Gaus Archid(iaco)nus et Vica(ri)us foraneus. HR-DARI-0275, Matična knjiga krštenih Rijeka (1675. - 1695.), knjiga 418, 27. studenoga 1684. De Franceschi navodi da je Gaus bio u Rijeci jedno desetljeće arhiđakon i vanjski vikar: ,parroco di Bolzano e poi dal 1683 di Fiume, quivi per un decennio arcidiacono e vicario foraneo“; De Franceschi, „Storia documentata“, 342-343. Funkcija arhiđakona i vanjskoga vikara su u Rijeci združene u jednu osobu još 1658. Poglayen, „Memorie cronologiche“, 121.

91 „parroco di Bolzano e poi dal 1683 di Fiume“; De Franceschi, „Storia documentata“, 342-343. Kandler će precizirati: „paroco di Bolzano in Tirolo“, ali bez navođenja vremena te njegove službe. Kandler, Pel fausto ingresso.

92 „abate di S. Giorgio in Canale“; De Franceschi, „Storia documentata“, 342. Kandler će napisati da je bio „Abbate di S. Giorgio in Canal“; Kandler, Pel fausto ingresso.

93 Jelinčić, Knjiga ređenja u Pićnu, 101.

94 Deković, „Pronađen autograf", 81. Laszowski navodi da je Lič, iako naseljen već u 15. st., bio samo kapelanija od kraja 18. st. sve do 1807., kada postaje župom. Župna crkva posvećena je sv. Jurju. Emilij Laszowski, Gorski kotar i Vinodol, Zagreb 1923., 59-60.

95 O fenomenu pokrštavanja „Turaka“ vidi: Zdenko Dundović, „Pokršteni Turci u Zadru u 17. stoljeću prema maticama krštenih katedralne župe sv. Stošije“, Radovi Zavoda za povijesne znanosti HAZU u Zadru, 59, 2017., 191-22 1; Danilo Klen, „Pokrštavanje ‘turske’ djece u Rijeci u XVI i XVII stoljeću“, Historijski zbornik (Šidakov zbornik, ur. Mirjana Gross), XXIX-XXX, 1977., 203-207.

96 HR-DARI-0275, Matična knjiga krštenih Rijeka (1675. - 1695.), knjiga 418, 30. prosinca 1691.; jednakom se titulacijom potpisao prilikom jednoga vjenčanja iz veljače 1692. HR-DARI-0275, Matična knjiga vjenčanih Rijeka (1675. - 1705.), knjiga 418, 14. veljače 1692.

97 Isto, 14. veljače 1693 . 
đen za nasljednika pokojnoga Marka Rossettija ${ }^{98}$ 9. ožujka 1693. ${ }^{99}$ Poslije toga je nadnevka u Rijeci početkom svibnja krstio kao confirmatus e(pisco)pus Petinensis. ${ }^{100}$ Za biskupa ga je posvetio pulski ordinarij Eleonoro Pagello $(1689 .-1695 .)^{101} \mathrm{uz}$ asistenciju dvojice opata. ${ }^{102}$

\section{Društvene i prirodne okolnosti na prijelomu stoljeća}

Gausovo upravljanje biskupijom u Pićnu zadesilo je više nevolja uzrokovanih ljudskim faktorom, ali i klimatskim čimbenicima. Miroslav Bertoša je istaknuo da je 17. i 18. st. u Istri bilo „razdoblje vremenskih nepogoda, jakih hladnoća, čestih suša“ ${ }^{103}$ Zapis anonimnoga pićanskog kroničara to potvrđuje prenoseći nam kako je 1701. bila „opća suša koja je prouzročila oskudicu prinosa pa je naredne godine bila takva glad da su u više mjesta muškarci, žene i djeca, kako ovdje u Istri tako u ostalim krajevima svijeta, umirali od gladi. Starić ${ }^{104}$ ječma se prodavao po 2 lire, a pšenice po 4 lire“. ${ }^{105}$ Pritom valja voditi računa da je od 80 do 90 \% stanovništva između 15. i 18. st. bilo seljačko i da je živjelo jedino od zemlje. ${ }^{106}$ Pićanci u tome dakako da nisu bili iznimka - i tamošnje se stanovništvo, kako pokazuje historiografija, pretežito bavilo poljoprivredom i stočarstvom. ${ }^{107}$

U političkom se smislu 18. stoljeće u Europi otvara Ratom za španjolsko nasljeđe. Naime, od 1701. do 1714. vladalo je ratno stanje između Austrije i Francuske. Borbe su se vodile i na prostoru Furlanije te na sjevernom Jadranu, stoga je putovanje i kopnom i morem bilo nesigurno. To je bio i dodatni razlog

98 O Rossettiju (Joannes Marcus Rossetti, 1689. - 1691.) kao pićanskom biskupu vidi: Grah, „Izvještaji pićanskih biskupa“, 10, bilj. 31 i ondje navedena literatura.

99 Miroslav Premrou, „Serie dei vescovi petinesi dal 1573-1798 secondo gli atti concistoriali dell'archivio segreto vaticano“(dalje: „Serie dei vescovi petinesi“), Archeografo triestino, 15, 1929./1930., 389.

100 Vidi bilj. 66.

101 Eleonorus Pajello (1689. - 1693.) prema Gamsu (Pius Bonifacius Gams, Series episcoporum ecclesiae catholicae, Ratisbonae 1873., 803), Eleonoro Pagello (1689. - 1695.) prema Bartoliću i Grahu (Marijan Bratolić - Ivan Grah, Crkva u Istri, 3. dopunjeno izdanje, Pazin 1999., 26). O tom pulskom biskupu vidi: Miroslav Bertoša, „Fragmenti vizitacije pulskoga biskupa Eleonora Pagella iz godine 1690.“, Croatica Christiana periodica, 46, 2000., 29-48, i literatura u bilj. 10.

102 Grah, „Izvještaji pićanskih biskupa“, 10.

103 Josip Vrandečić - Miroslav Bertoša, Dalmacija, Dubrovnik i Istra u ranome novom vijeku, Zagreb 2007., 100. 104 Starić kao mjera za količinu žitarica iznosio je 10,83 litara. Ivan Grah, „Urbar Pićanske biskupije (16171621). Povijesni pregled“ (dalje: „Urbar Pićanske biskupije“), Vjesnik historijskih arhiva u Rijeci Pazinu, 16, 1971., 270.

105 HR-HDA-819, Vjekoslav Spinčić, kutija 134 (fragmenti Pićanskog kaptola), bez paginacije. Pripremamo za objavu ondje sadržane kroničarske zapise koje smo na ovome mjestu skraćeno prepričali.

106 Fernand Braudel, Materijalna civilizacija, ekonomija i kapitalizam od XV. do XVIII. stoljeća, knjiga I, Strukture svakidašnjice, Zagreb 1992., 39.

107 Danijela Juričić Čargo, „Gospodarsko stanje na posjedima pićanskih biskupa sredinom XVIII. stoljeća“ (dalje: „Gospodarsko stanje“), Pićanska biskupija i Pićanština, zbornik radova međunarodnog znanstvenog skupa održanog 23. i 24. listopada 2008. godine, glavni i odgovorni urednik Robert Matijašić, Pazin 2012., 63. 
da Gaus odustane od puta u Rim, kamo je trebao odnijeti izvještaj o stanju u biskupiji. ${ }^{108}$ Strah koji se u to vrijeme širio sjevernim Jadranom bilježi isti pićanski kroničar navodeći da je 24. rujna 1702. opljačkan i dijelom spaljen Pićnu nedaleki Lovran. Iz župne su crkve sve kaleže, srebrne svijećnjake i piksidu iz tabernakula te neka zvona iz poljskih crkava odnijeli „zloglasni Francuzi“ (infami francesi), koji su napad počinili noću. Lovranci su se tako prestrašili da su pobjegli ostavivši širom otvorena vrata mjesta.

Neobičan meteorološki događaj zbio se 12. lipnja 1704., kada je prigodom proslave blagdana Tijela Gospodnjega na Učki pao obilan snijeg. I naredne godine, 28. svibnja 1705., palo je puno snijega na Učki i oko nje kao da je zima. ${ }^{109}$ Takve vremenske nepogode nisu bile nešto što bi karakteriziralo samo Pićanštinu. Bilo je toga i u drugim krajevima, što pridonosi sintagmi „maloga ledenog doba“ početkom 18. stoljeća i na tome mikrolokalitetu. ${ }^{110}$

Sa svih strana se čulo, nastavio je bilježiti anonimni mjesni kroničar, da je vremenska nepogoda 1709. poharala ne samo Pazinsku knežiju nego cijelu Istru i ostale krajeve toliko jakom sušom i poledicom da su se svi nasadi smokava pa i svi maslinici osušili, a što se sve obrušilo i na Pićanštinu. ${ }^{111}$ Velika zima bila je i 1711. godine. ${ }^{112}$

Pri kraju Gausova života i upravljanja biskupijom taj su širi kraj zahvatile nove pošasti - bile su to suša i kuga 1713./1714., što je - uz spomenuti rat dovelo do zabrane putovanja. ${ }^{113}$

Nedvojbeno je i biskupa Gausa, bilo da je stanovao u Pićnu ili u Rijeci, dotaknula ta tegobna stvarnost. Živeći, kako ćemo pokazati, revnu pastoralnu aktivnost, kojoj nije uzmanjkalo doticaja sa seljačkim svijetom koji je činio socijalno-ekonomski okvir njegova pastoralnog djelovanja, uviđao je, a zacijelo dijelom i sam proživljavao oporost života, bojazni i nade povjerene mu pastve.

Smrt kao prirodna sastavnica života nedvojbeno ga je najmanje u dva navrata trgnula zbog dramatičnoga povećanja broja umrlih 1694. i 1702.

108 Zrinka Novak, „Hrvatski vojnici na europskim bojištima“, U potrazi za mirom i blagostanjem. Hrvatske zemlje u 18. stoljeću, ur. Lovorka Čoralić, Zagreb 2013., 485; Grah, „Izvještaji pićanskih biskupa“, 10, 21 i literatura u bilješci 34; Pio Paschini, Storia del Friuli, vol. II, Udine 1954., 430; Kobler, Memorie II, 208; Kandler, Indicazioni, 79.

109 HR-HDA-819, Vjekoslav Spinčić, kutija 134 (fragmenti Pićanskog kaptola).

110 Hrvoje Petrić, ,,Neke bilješke o 'malom ledenom dobu' (s malim osvrtom na Istru)“, Zbornik javnih predavanja 2, ur. Maja Cerić i Mirela Mrak, Pazin 2013., 154.

111 HR-HDA-819, Vjekoslav Spinčić, kutija 134 (fragmenti Pićanskog kaptola). I u Rijeci je 1709. zabilježena velika zima, koja je za posljedicu imala uništenje maslinika (Kobler, Memorie III, 208).

112 Kandler, Indicazioni, 80.

$113 \mathrm{Na}$ ist. mj.; Grah, „Izvještaji pićanskih biskupa“, 10 i literatura u bilješci 35. 
(vidi tablicu 1). Pritisnut godinama, bolovima i sviješću o nužnosti odlaska s ovoga svijeta, u ponedjeljak 17. rujna 1714. pozvao je u biskupsku palaču u Pićnu nekolicinu svećenika i laika te notara odlučivši sastaviti oporuku.

Tablica 1. Broj umrlih u Pićnu po godinama ${ }^{114}$

\begin{tabular}{|c|c|c|c|}
\hline Godina & Broj umrlih & Godina & Broj umrlih \\
\hline 1693. & 16 & 1705. & 11 \\
1694. & 52 & 1706. & 7 \\
1695. & 6 & 1707. & 23 \\
1696. & 10 & 1708. & 30 \\
1697. & 12 & 1709. & 26 \\
1698. & 7 & 1710. & 13 \\
1699. & 10 & 1711. & 7 \\
1700. & 11 & 1712. & 15 \\
1701. & 53 & 1713. & 9 \\
1702. & 11 & 1714. & 16 \\
1703. & 26 & 1715. & 20 \\
1704. & & 1716. & \\
\hline
\end{tabular}

\section{Upravljanje biskupijom}

Papa Siksto V. (1585. - 1590.) je konstitucijom Romanus Pontifex, donesenom 20. prosinca 1585., odredio da biskupi s područja Italije, jadranskih otoka i susjednih krajeva Grčke trebaju posjetiti pragove apostola, tj. Rim, i podnijeti izvještaj o stanju u svojoj biskupiji jednom u tri godine, a biskupi s područja Njemačke, Francuske, Engleske, Španjolske i drugih zemalja sa sjevera, kao i mediteranskih otoka, jednom u četiri godine. ${ }^{115}$ Bosanski i srijemski biskupi bili su dužni te pohode obaviti također svake četvrte godine. ${ }^{116}$ Relativno je lako uočljiva neredovitost postupanja pićanskih biskupa sukladno toj konstituciji, a razlozi su bili raznoliki. Neredovitost u popunjavanju biskupske stolice jedan je od razloga, potom su tu bolesti koje su biskupe prikovale za krevet, protuepidemijske mjere koje su ograničavale kretanje, politička stanja i ratovi, obaveze biskupa izvan biskupije, ali i siromaštvo same biskupije, što je također navođeno kao jedan od razloga takvom postupanju.

114 ŽAP, Matična knjiga umrlih Pićan (1664. - 1776.).

115 William E. Addis, A catholic dictionary, London 2015., s.v. „Visitatio liminum apostolorum“.

116 Antun Dević, „Vatikanski dokumenti Đakovačke i Srijemske biskupije u XVII. i XVIII. stoljeću“, Fontes: izvori za hrvatsku povijest, 4, 1998., 15. Primjerice, prvi je biskup sa slovenskog područja poslao izvještaj u Rim nakon isteka četiri godine (1589.). France Martin Dolinar, Poročila ljubljanskih škofov v Rim o stanju v škofiji (relationes ad limina), I. del: 1589-1675., Ljubljana 2011., 24-25. 
U dvadeset i tri godine upravljanja Pićanskom biskupijom Gaus je poslao u Rim pet izvještaja o stanju u Biskupiji. Bilo je to 1697., 1701., 1705., 1711. i 1714. godine. ${ }^{117}$ Kada je došao na Katedru sv. Nicefora, mogao je konstatirati da preko dvadeset godina iz Pićna nije u Rim poslano nijedno izvješće. Usporedimo li ga s drugim pićanskim biskupima, zamijetit ćemo da je Gaus bio najaktivniji u povijesti te dijeceze otkad je ta obveza donesena (vidi tablicu 2). Međutim, njegovo putovanje u Rim za ispunjenje te zadaće nije ostvareno zbog upale zglobova nogu i ruku te kamenaca. Konstatirao je, naime, da su podagra, chiragra i calculi bolesti koje ga muče. Nadalje, oskudica što je pratila biskupiju Gausova upravljanja onemogućila mu je da svoje svećenike šalje na tako dalek i financijski zahtjevan put. Zbog tih razloga kao opunomoćenike izabire isusovce koji su djelovali u Svetome Gradu kao hrvatski ispovjednici: Marka Ljubičića i Zahariju Gladića. ${ }^{118}$

Tablica 2. Izvještaji pićanskih biskupa Svetoj Stolici ${ }^{119}$

\begin{tabular}{|c|c|c|}
\hline Biskup & Godine izvještaja & Ukupan broj izvještaja \\
\hline Georgius Reitgartler (1570. - 1600.) & 1589., 1593., 1595. & 3 \\
\hline Antonius Zara (1601. - 1621.) & 1606., 1614., 1620. & 4 \\
\hline Pompeus Coronini (1625. - 1631.) & 1628. & 1 \\
\hline Gasparus Bobeck 1631. - 1635.) & - & 0 \\
\hline Antonius Marenzi (1637. - 1646.) & 1644. & 1 \\
\hline Franciscus Vaccanus (1649. - 1663.) & 1656., 1661. & 2 \\
\hline Paulus de Tauris (1663. - 1667.) & 1666. & 1 \\
\hline Paulus Budimir (1668. - 1670.) & - & 0 \\
\hline Andreas Daniel Raunoch (1670. - 1686.) & 1675. & 1 \\
\hline Joannes Marcus Rossetti (1689. - 1691.) & - & 0 \\
\hline Petrus Antonius Gaus (1693. - 1716.) & $\begin{array}{c}\text { 1697., 1701., } 1705 ., \\
\text { 1711., } 1714 .\end{array}$ & 5 \\
\hline $\begin{array}{l}\text { Georgius Franciscus Xaverius Marotti } \\
\qquad(1716 .-1740 .)\end{array}$ & - & 0 \\
\hline $\begin{array}{l}\text { Josephus Bonifacius de Cecotti } \\
\qquad(1741 .-1765 .)\end{array}$ & $\begin{array}{l}1756 ., 1760 . \\
1764 . / 1765 .\end{array}$ & 3 \\
\hline $\begin{array}{l}\text { Aldragus Antonius de Piccardi } \\
\qquad(1766 .-1785 .)\end{array}$ & 1770., 1775., 1780. & 3 \\
\hline
\end{tabular}

117 Grah, „Izvještaji pićanskih biskupa“, 10. 
Biskup Gaus je, kako iščitavamo iz njegovih izvještaja Svetoj Stolici, predsjedavao liturgijskim slavljima za veće blagdane, obavljao kanonske vizitacije te prema potrebi održavao biskupijske sinode. ${ }^{120}$ Poznato nam je da je obvezu vizitiranja podređenih župa i kuracija obavio u tri navrata, i to 1694., ${ }^{121} 1697 .{ }^{122}$ i $1699 .{ }^{123} \mathrm{O}$ crkvenim saborima za Pićansku biskupiju u vrijeme Gausova biskupovanja nemamo sačuvanih podrobnijih obavijesti. ${ }^{124} \mathrm{Kad}$ je u pitanju mjesto rezidiranja, valja nam napisati da već podatak o Gausovu dvostrukom izboru mjesta ukopa - Pićan ili Rijeka - u neku ruku potvrđuje konstataciju Marottija, ${ }^{125}$ njegova nasljednika na pićanskoj biskupskoj katedri. On, naime, tvrdi da je tijekom svoje biskupske službe Gaus 16 godina živio u gradu svojega rođenja. ${ }^{126}$ Tu je i zapis jednoga pićanskog krštenja iz 1703., koji kaže da ga je obavio Ivan Krstitelj de Jacomettis, kanonik, generalni vikar presvijetloga i prečasnoga antistitis Petri Antonij Gaus Fluminensis. ${ }^{127}$ Zacijelo je ovdje uporabljeni prezimenski pridjevak odraz pojačanoga dojma Pićanaca neprijeporne biskupove povezanosti s Rijekom.

Tridentski koncil je o pitanju rezidencije biskupa bio posve određen te nije dopuštao ordinarijima da izbivaju više od tri mjeseca kontinuirano iz svoje biskupije, osim u opravdanim slučajevima. ${ }^{128}$ Razlog njegova dugotrajnoga izbivanja iz Pićna možemo tražiti u bolesti i potrebi intenzivnije liječničke skrbi, koju mu je Rijeka kao značajnije urbano središte sjevernoga Jadrana omogućavala. Valja spomenuti da su u Gradu Svetoga Vida prvi pravi ljekarnici i ljekarne zabilježeni tek u 18. st., ${ }^{129}$ pri čemu je prva apoteka otvorena 1709., što je nepobitno uzrokovalo Gausove češće posjete tome gradu.

Posljednje tri godine svoje biskupske službe nije obavio nijedno ređenje, što je, prema Jelinčiću, bilo uzrokovano njegovim zdravstvenim stanjem. ${ }^{130}$

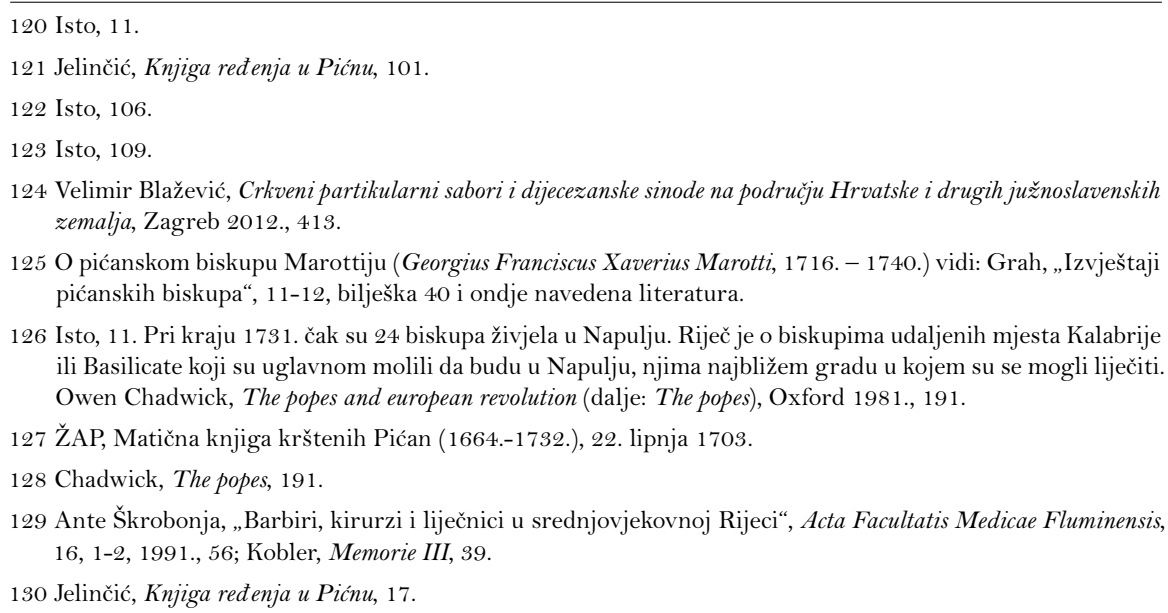


Pismom od 20. svibnja 1710. biskup Gaus obratio se markizu de Prieu tražeći zbog bolesti imenovanje jednoga koadjutora. Ercole Giuseppe Lodovico Turinetti, markiz de Prie, kao pazinski grof imao je jus nominandi ad episcopatum Petinensem. Naime, pravo imenovanja je baštinio od prošlih vlasnika grofovije koji su u slučajevima vakantnosti pićanske biskupske katedre caru predlagali kandidata za tu službu. U Rimu je 22. svibnja 1713. Gausova želja uslišana te je dobio koadjutora cum futura successione Jurja Franju Ksaverskog Marottija. Taj je svećenik Pulske biskupije imenovan naslovnim biskupom Dardanije. ${ }^{131}$

\section{Pabirci o prihodima i dušobrižništvu}

Detalji o ekonomskim mogućnostima Pićanske biskupije, njezinim svećenicima i stanovništvu skromno nam se otkrivaju kroz izvještaje što ih je Gaus slao u Rim. Biskupov prihod je 1697. iznosio 120 škuda, a 1705. i 1711.300 forinti. Taj mu je iznos od 300 forinti bio dovoljan za tri mjeseca življenja u 1714., ${ }^{132}$ kako je Gaus pedantno izvještavao Svetu Stolicu. Ono što mu je možda pridonosilo osobnoj ekonomiji bila je služba carskoga savjetnika. Pouzdano znamo da je bio i feudalni gospodar beneficija Gologorice, ${ }^{133}$ a prema Urbaru Pićanske biskupije proizlazi da su prihodi biskupa dolazili i od alodijalnih dobara Tupljaka i Škopljaka, čiji su seljaci bili podložnici isključivo pićanskoga biskupa kao feudalnoga gospodara. Tome treba pribrojiti i urbarijalna podavanja i obaveze ostalih mjesta biskupije (uključivo Stari Pazin), kao i 1692. popisane biskupijske nekretnine u okolici Pićna - u Tupljaku, Škopljaku i Gračišću. ${ }^{134}$

Katedrala je, prema Gausu, imala male prihode od vina što ih sindici i gastaldi skupe od podložnika. Da bi predočio malenost spomenutih prihoda, piše da je prihod takav da tek pokriva troškove za hostije, misno vino i ulje za vječno svjetlo pred Presvetim. ${ }^{135}$

\footnotetext{
131 Premrou, „Serie dei vescovi petinesi“, 389. Marotti je kao pomoćni pićanski biskup 1715. okrunio sliku Gospe Trsatske. To je bilo prvo krunjenje izvan Italije, a dvije godine poslije bit će okrunjene čudotvorne slike u Częstochowi u Poljskoj i na Svetoj Gori u (današnjoj) Sloveniji. Franjo Emanuel Hoško, Trsatski franjevci. Pet i pol stoljeća služenja Trsatskom svetištu, Trsat 2004., 185.

132 Grah, „Izvještaji pićanskih biskupa“, 10; isti, „Pazinski kraj u izvještajima pićanskih i porečkih biskupa Svetoj Stolici (1588-1780““ (dalje: „Pazinski kraj u izvještajima“), Croatica Christiana periodica, 26, 1983., 211.

133 ŽAP, Oporuka, 2; ŽAP, Kodicil A. Gologorica je imala svoj urbar i često je bila dodjeljivana pićanskim biskupima zbog njihovih slabih prihoda. De Franceschi, „Storia documentata“, 376, 377.

134 Urbar je dao sastaviti Antonio Zara (1601. - 1621.), a prepisao ga je 1772. svećenik Petar Aničić (1752. 1809.). Grah, „Urbar Pićanske biskupije“, 268, 269., 280. O Aničiću vidi: Jelinčić, Knjiga ređenja u Pićnu, 277 ; postoji i prijepis Urbara Pićanske biskupije iz 1692. koji je dijelom obradila Juričić Čargo (Juričić Čargo, "Gospodarsko stanje“, 63-64).

135 Grah, „Izvještaji pićanskih biskupa“, 10.
} 
Katedralni kaptol se sastojao od tri do pet kanonika, koji su također bili u oskudici jer bez osobne imovine i prihoda ne bi mogli preživjeti. Jedan je kanonik živio na teret zajednice.

Štolarina je ostala neizmijenjena u odnosu na podatke iz 1675. godine. Za tihu misu plaćalo se 8 novčića ili 5 bajoka (bagiochio), ${ }^{136}$ a za pjevanu misu 12 novčića ili 7 bajoka. Taksa za sprovod iznosila je hljeb kruha, mjeru vina i sitnu voštanicu vrijednu jedan novčić. ${ }^{137}$ Iz toga proizlazi da je materijalna vrijednost jedne pjevane mise bila jednaka vrijednosti 12 sitnih voštanica.

Pastoralna aktivnost Pićanštine odvijala se nad stanovništvom kojega je broj osjetno varirao, od oko 4000 duša 1697. do oko 6000 duša 1714. godine. ${ }^{138}$ Kanonicima je bila povjerena duhovna skrb nad stanovništvom Pićna i okolnih sela. ${ }^{139}$

Na području cijele biskupije u Gausovo vrijeme poznate su nam svega tri župe: Gračišće, Lindar i Novaki, a broj župnika ne koincidira s tim podatkom već ih je 1714. bilo četiri. Uz župe supostojao je još niz područnih crkava, tzv. curatae ecclesiae, kojih se broj kao i kurata razlikovao kroz godine. Tako 1697. zatječemo osam, 1705. sedam, a 1711. jedanaest kuracija. Od redovnika u Pićanskoj biskupiji postojala je samo jedna zajednica pavlina smještena u najstarijem pavlinskom samostanu u Istri, onom Majke Božje na Jezeru ${ }^{140} \mathrm{u}$ Čepiću, u kojem su obitavala tri do četiri pavlina. ${ }^{141}$

Uvid u brojnost klera, kao i u njihova osobna imena u Pićnu moguće je dobiti temeljem sačuvanih matičnih knjiga i za Gausovo razdoblje. Nakon smrti biskupa Rossettija u studenom 1691., Katedra sv. Nicefora će ostati vakantna do rimske potvrde Gausa u ožujku 1693. godine. U tom vremenskom procjepu kao kapitularni vikar djelovat će Ivan Krstitelj de Jacomettis, koji je ujedno bio i kanonik pićanske katedrale. ${ }^{142}$ On će se od kraja listopada 1693. navoditi kao kanonik i generalni vikar, ${ }^{143}$ što znači da ga je novi biskup Gaus izabrao za svojega najbližeg suradnika i na toj je službi ostao kroz cijelo

\footnotetext{
136 Bajok (bagioco, baiocco, bagiochio) je rimski (papinski) bakreni novac, u protuvrijednosti dva venecijanska solida. Giuseppe Boerio, Dizionario del dialetto veneziano, Venezia 1856., 2006., 55.

137 Grah, „Izvještaji pićanskih biskupa“, 10.

138 Isto, 11; isti, „Pazinski kraj u izvještajima“, 211.

139 Isti, „Izvještaji pićanskih biskupa“, 10.

140 Marijan Bradanović, „Pavlinski samostan Bl. Dj. Marije na Čepićkom jezeru“, Pićanska biskupija i Pićanština, 191-207 i ondje navedena literatura.

141 Grah, „Izvještaji pićanskih biskupa“, 11.

142 Joannes Baptista de Jacomettis Canonicus nec non Vicarius Capitularis (ŽAP, Matična knjiga krštenih Pićan [1664. - 1732.], 4. siječnja 1693.).

143 Joannes Baptista de Jacomettis Canonicus huius Cathedralis nec non Vicarius Generalis (ŽAP, Matična knjiga krštenih Pićan [1664. - 1732.], 26. listopada 1693.).
} 
vrijeme Gausova biskupovanja. Druga važna služba u upravi biskupijom, ona arhiđakona, pripadala je najprije Ivanu Niceforu Zagliću, ${ }^{144}$ koga će na tom položaju zamijeniti Marin Josip Bellazzi. Potonji nam se najprije otkriva kao župnik Nove Vasi koja je pripadala Pulskoj biskupiji, ali je u državno-teritorijalnom smislu ulazila u sklop Austrije. ${ }^{145}$ Ubrzo će od natpopa i počasnoga kanonika pićanske katedrale ${ }^{146}$ postati arhiđakon i kanonik ${ }^{147}$ te će nositi i zvučnu titulu apostolskoga protonotara de numero participantium. ${ }^{148}$

Pićanski kaptol su od 1693. do 1716. sačinjavali naredni prezbiteri: Marin Josip Bellazzi, Martin Gasprotić, ${ }^{49}$ koji će biti i arhiđakon, ${ }^{150}$ Sante Hainoga, ${ }^{151}$ koji će 1703 . biti naveden kao mansionar, ${ }^{152}$ a od 1712. kao kanonik, ${ }^{153}$ Petar Ruvis, ${ }^{154}$ Šimun Sanković, kapelan biskupa Gausa i naslovni kanonik pićanske katedrale, ${ }^{155}$ da bi u svibnju 1702. bio naveden kao kanonik, ${ }^{156}$ te Jakov de Vicho. ${ }^{157}$

Osim navedenih kanonika, ostali svećenici koji su obavljali krštenja u Pićnu bili su: Sebastijan Stanić, ${ }^{158}$ Martin Lizzal iz Šumbera (de Sussberg), ${ }^{159}$ Gabrijel Škampić, koji je bio i savjetnik Svetoga Oficija, ${ }^{160}$ te Petar Šuperini, majordom baruna Bridija (Brigida?). ${ }^{161}$

\footnotetext{
144. Joannes Nicephorus Zaglich Archidiaconus (ŽAP, Matična knjiga krštenih Pićan [1664. - 1732.], 10. rujna 1693.).

145 Ville Nove Polensis Diecesis ex parte Imperii (ŽAP, Matična knjiga krštenih Pićan [1664. - 1732.], 19. ožujka 1694.). Danas u Općini Kršan.

146 Marinus Josephus Bellazzi Archipresbyter Canonicus honorius huius Cathedralis atque Parochus Villa nova Polensis a parte Imperij diecesis (ŽAP, Matična knjiga krštenih Pićan [1664. - 1732.], 3. srpnja 1699.).

147 ŽAP, Matična knjiga krštenih Pićan (1664. - 1732.), 18. studenoga 1703.

148 Isto, 14. veljače 1706.; o tituli apostolskoga protonotara vidi: http://www.treccani.it/enciclopedia/protonotario-apostolico_\%28Enciclopedia-Italiana\%29/ (pristup 6. svibnja 2020.).

149 ŽAP, Matična knjiga krštenih Pićan (1664. - 1732.), 24. siječnja 1697.

150 Isto, 12. ožujka 1699. (upis je unutar 1698.!); isto, 9. ožujka 1699.

151 P(presbyter) Sanctus Hainoga (isto, 15. listopada 1693.); u obliku Santus Hainoga (isto, 23. travnja 1699.).

152 Isto, 16. listopada 1703. Mansionarija je oblik nadarbine.

153 Can(onic)us Santus Hainoga (isto, 14. siječnja 1712.).

154 Petrus Ruvis Canonicus (isto, 15. veljače 1693.).

155 Simon Sancovich Capellanus Ill(issi)mi ac Rev(erendissi)mi Do(mi)ni Do(mi)ni Petri Antonij Gaus ab'Omperg Eppiscopi Petenensis nec non Canonicus Titularis huius Cathedralis (isto, 7. rujna 1699.).

156 Isto, 6. svibnja 1702.

157 Isto, 12. prosinca 1705 .

158 Presb(yt)er Sebastianus Stanich (isto, 25. siječnja 1693.).

159 Isto, 16. kolovoza 1698. Zacijelo je riječ o Šumberu (Sumberg).

160 Gabriele Scampich, Consigliere dello Santo Offizio (ŽAP, Matična knjiga krštenih Pićan [1664. - 1732.], 25. ožujka 1700.). Gabrijel Škampić je kao kandidat iz Labina 1651. primio red egzorcistata (Jelinčić, Knjiga ređenja u Pićnu, 50).

161 Rev(erend)us Petrus Superini (ŽAP, Matična knjiga krštenih Pićan [1664. - 1732.], 5. listopada 1702.).
} 
Sakrament vjenčanja su u Gausovo vrijeme biskupovanja dijelili: kanonik Petar Ruvis, ${ }^{162}$ kanonik i kapitularni pa generalni vikar Ivan Krstitelj de Jacomettis, ${ }^{163}$ kanonik Martin Gasprotić ${ }^{164}$ te arhiđakon i kanonik Marin Josip Bellazzi. ${ }^{165}$ Biskup Gaus nije sjedinio u brak nijedan par u Pićnu.

\section{Gaus kao djelitelj sakramenata od 1693. do 1716.}

Povezanost s rodnim gradom očitovala se i nakon Gausova preseljenja na novu službu u Pićan posredstvom dijeljenja sakramenata. Tako je u Rijeci početkom svibnja 1693. krstio kao confirmatus e(pisco)pus Petinensis dijete Ernesta i Sidonije Spingaroli, biskupove sestre. ${ }^{166}$ U Rijeci je krstio i Franju Karla, sina Ferdinanda i Franjice Zanchi $1700{ }^{167}$

Gaus je prvo krštenje kao pićanski biskup obavio krajem siječnja 1694. godine. Krstio je Ivana, sina župana Jurja Težaka i supruge mu Uršule. Kumovi su na ovom krštenju bili veprinački župnik Ivan Mikuličić i Marina, supruga župana Krstitelja Rovisa. ${ }^{168}$ Potom je u lipnju 1695. krstio Ivana Nicefora, sina Kristofora i Apolonije Hainoge. Kumovi su bili iz Novaka i Boljuna. Tom se prilikom biskup navodi i kao carski savjetnik. ${ }^{169}$ Iz navedenih kumstava se u nekoj mjeri raspoznaje društvena povezanost Pićanaca $s$ istočnom, priobalnom Istrom.

Istoga je dana Gaus krstio i dijete Antuna i Jurje Gidin. ${ }^{170} \mathrm{U}$ oba slučaja upis u maticu krštenih je obavio arhiđakon Zaglić. Krstio je i u travnju 1696. sina obitelji Scarpin. ${ }^{171}$ Nekoliko dana poslije krstio je dijete obitelji Bajša, a kumovi su bili Ivan Krstitelj de Jacomettis, generalni vikar i kanonik pićanske katedrale, i Ivan de Tore, župnik i natpop Novaka. ${ }^{172}$ Biskup je u prosincu 1696. krstio sina župana Jurja Težaka, čiji su kumovi bili Petar Ančić, župnik Čepića, i Ivana, supruga Franje Jerbula iz Gračišća. ${ }^{173}$ Zadnje Gausovo krštenje u Pićnu je iz svibnja $1697 .{ }^{174}$

162 ŽAP, Matična knjiga vjenčanih Pićan (1664. - 1775.), 12. svibnja 1694.

163 Isto, 1. veljače 1693.

164 Isto, 4. veljače 1698.

165 Isto, 7. studenoga 1702.

166 HR-DARI-0275, Matična knjiga krštenih Rijeka (1675. - 1695.), knjiga 418, 4. svibnja 1693.

167 HR-DARI-0275, Matična knjiga krštenih Rijeka (1695. - 1705.), knjiga 418, 28. srpnja 1700.

168 ŽAP, Matična knjiga krštenih Pićan (1664. - 1732.), 29. siječnja 1694.

169 Sac(rae) Ces(areae) Mae(sta)tis Consiliario (isto, 7. lipnja 1695.).

$170 \mathrm{Na}$ ist. mj.

171 Isto, 5. travnja 1696.

172 Isto, 10. travnja 1696.

173 Isto, 6. prosinca 1696.

174. Isto, 5. svibnja 1697. 
Potvrdu, tj. krizmu kao jedan od sakramenata kršćanske inicijacije redovito podjeljuje biskup, za razliku od krštenja i pričesti. ${ }^{175}$ Gaus je kao djelitelj krizme naveden 1694. u Pićnu, kojom je prilikom krizmao 96 djece. ${ }^{176}$ U Gračišću je njegov upis kao krizmatelja tada tipičnoga baroknog sloga: Confirmati ab Ill(ustrissi)mo et R(everendissi)mo D(omi)no D(omi)no Petro Antonio Gaus de Homperg Episcopo Petenensi Sacre Cesaree Maiestatits Consiliario etc. Ondje je 15. lipnja 1694. krizmao ukupno 79 kandidata iz te župe. ${ }^{177}$

Kao možda najprepoznatljiviji oblik obnašanja biskupske dužnosti u vidu njegova sakramentalnoga djelovanja, biskup Gaus je obavljao sveta ređenja, kako u Pićnu, tako i u drugim mjestima svoje biskupije, ali i izvan nje, i to kontinuirano od 1693. do 1703. i 1713. godine. ${ }^{178}$ Prema Jelinčiću, Gaus je ukupno imao 114 ređenika, a podijelio je 411 redova i 22 tonzure. U odnosu na ostale reditelje u 151 godini povijesti te dijeceze (1632. - 1783.), Gausu pripada treće mjesto po broju ređenika, odmah nakon Cecottija i Piccardija. ${ }^{179}$

Kandidati za svete redove dolazili su pred biskupa Gausa iz dva politički-administrativno različita područja: austrijske Istre, Primorja i Kranjske (Bakar, Boljun, Brseč, Gologorica, Gračišće, Grobnik, Lovran, Ljubljana, Mošćenice, Pazin, Pazinski Novaki, Rijeka, Veprinac, Zarečje, Žminj) te venecijanske Istre (Barban, Grimalda, ${ }^{180}$ Labin, Piran, Sveti Lovreč, Sveti Ivan od Šterne). Već ovaj popis mjesta njihove provenijencije ukazuje i na njihovu različitu dijecezansku pripadnost koja nije redovito zabilježena do razine mjesta (Akvilejska, Koparska, Modruška, Pićanska, Porečka i Pulska biskupija).

Osim dijecezanskih kandidata, pred Gausa su dolazili i pripadnici nekoliko redova: franjevci (Red male braće), Treći franjevački red i Red svetog Pavla prvog pustinjaka.

Gausov je prethodnik na pićanskoj biskupskoj katedri, biskup Rossetti, svete redove podjeljivao isključivo u Pićnu, i to u katedrali ili u kućnoj kapeli sv. Ane.

\footnotetext{
175 Katekizam Katoličke crkve, Zagreb 1994., 346-348.

176 ŽAP, Matična knjiga vjenčanih Pićan (1664. - 1732.). Upis je unutar ove matice koja nije paginirana.

177 ŽAG, Matična knjiga krštenih Gračišće (1667. - 1745.), na kraju ove matice je popis krizmanih za 1690. i 1694. godinu.

178 Jelinčić, Knjiga ređenja u Pićnu, 19. Podatci za ovo poglavlje, ako drugačije nismo naveli, preuzeti su iz toga objavljenog izvora (tj. Jelinčićeva priređivačkoga rada) na stranicama 101-114, 121-122.

179 Isto, 19.

180 Grimalda je potpadala u crkvenom smislu pod Pićansku biskupiju, a u svjetovnom pod Veneciju. Grah, „Izvještaji pićanskih biskupa“, 1, 3, 5, 13-15.
} 
Gaus je redio u nizu mjesta svoje biskupije. Tako ga zatječemo u Gračišću, gdje je 15. lipnja 1694. prilikom vizitacije u crkvi sv. Vida podijelio tonzuru i prva četiri reda franjevcu Malahiju Proesogliu, Jurju Leveriću iz Čepića i Martinu Dobriću iz Rijeke. Pavlinskom kandidatu Bernardu Gaspariniju je u crkvi sv. Bartola u Tupljaku na spomendan toga sveca (24. kolovoza 1697.) podijelio četiri niža reda i podđakonat. Nakon svega nekoliko dana, u crkvi sv. Jurja u selu Brdo, gdje je obavljao vizitaciju, istome je fratru podijelio đakonat. U konačnici je u crkvi Blažene Djevice Marije ad Lacum, što je crkva uz pavlinski samostan, 8. rujna 1697. podijelio spomenutom fra Gaspariniju red prezbiterata. Redio je Gaus i u Pićnu u katedrali te u kućnoj kapeli Blažene Djevice Marije. Potom je u župnoj crkvi svetih Hermagore i Fortunata u Lindaru (in ecclesia parochiali villae Lindarii) podijelio tonzuru i četiri niža reda Šimunu Sankoviću iz Rijeke. U crkvi sv. Lovre pokraj Rijeke, koja se nalazila na prostoru Modruške biskupije, istom je kandidatu dao red đakonata. U toj je crkvi redio u više navrata. Redio je i u Gologorici, a prilikom vizitacije Svetoga Ivanca (Sutivanca) zaredio je za svećenika franjevca Antuna Premuža (1699.). Činjenica da je dijelio tonzure i svete redove po okolnim mjestima otkriva nam ga kao duhovnoga pastira koji je u svom pastoralu kanio približiti svetim činima ređenja veće mnoštvo naroda, i to dokle god mu je zdravlje dopuštalo.

Svojem ukućaninu i mogućem rođaku Josipu Antunu Tudoroviću, kasnijem kanoniku i riječkom dekanu, ${ }^{181}$ podijelio je tonzuru i četiri niža reda u veljači 1695., na Veliku subotu iste godine podijelio mu je red podđakonata, a u travnju 1696. red đakonata.

Već smo napisali kako se zadnje godine Gausova života (1713. - 1716.) preklapaju s dodijeljenim mu koadjutorom cum iure successionis kojega je dobio u osobi svojega sugrađanina, Riječanina Jurja Franje Ksaverskog Marottija. $\mathrm{U}$ tom razdoblju nemamo sačuvanih zapisa da je obavljao ređenje, osim $\mathrm{u}$ svibnju 1713. godine. ${ }^{182}$

181 Deković, „Pronađen autograf“, 84. Josip Tudorović je u Knjizi ređenja navođen kao rediteljev familiaris. To je značilo da je neko vrijeme živio s biskupom, no ne nužno da je bio i njegov rođak. Tako se, primjerice, u vizitacijama Zagrebačke biskupije s kraja 17. st. pod izrazom de familia habet navodi najbliža rodbina, ali i razne sluge te kuharice koji su svi živjeli pod istim krovom dotičnoga kanonika. Andrija Lukinović, „Vizitacije zagrebačkog kaptola u XVII. stoljeću“, Croatica Christiana periodica, 23, 1989., 67-89. 


\section{(Ne)posredni iskazi Gausove pobožnosti}

Jedan od načina iskazivanja pobožnosti pa tako i njihova historiografskoga iščitavanja moguć je kroz zapise u oporukama i kodicilima. Kako je pobožnost što se odražava kroz oporuke u izravnoj svezi s naukom o Čistilištu, valja napomenuti da je Crkva nauk o Čistilištu jasno izrazila na Firentinskom i Tridentskom koncilu pozivajući se na crkvenu predaju i na neka mjesta Svetoga pisma. ${ }^{183}$ Oporučitelj, svjestan svoje grješnosti i nesavršenosti, pouzdaje se u molitve svojih nasljednika, tj. bližnjih, da bi mu pomogle u konačnom čišćenju nakon smrti, a prije odlaska u raj. ${ }^{184}$

Biskup Gaus, prema zapisima njegove posljednje volje iz rujna 1714., osobito je vodio računa o spasenju vlastite duše. Zapravo, svoju je oporuku, kako izravno u njoj i navodi, dao sastaviti iz pobožnih razloga. ${ }^{185}$ Većina njegovih oporučnih legata bila je upravo u tom smislu i namijenjena. Možemo izdvojiti tek dvije značajnije ostavštine koje izravno nisu bile potaknute pobožnošću. Tako je svojoj sestri i glavnoj nasljednici ostavio 1000 forinti, koje joj je ranije dao, bez posebne napomene o nekoj njezinoj pobožnoj dužnosti. Doduše, kao glavna nasljednica bila je dužna rasporediti preostala dobra, nakon raspodjele sukladne oporuci, u pobožne svrhe. ${ }^{186}$ Isto je tako i nećaku Ksaveru Gausu ostavio svoja nepokretna dobra, bilo da ih je naslijedio ili kupio vlastitim novcem, kao i dugove svojega dužnika, također ne tražeći od njega određeno pobožno djelo za spas svoje duše. ${ }^{187}$ Pri završnom dijelu oporuke napominje kako su navedeni pobožni legati ustanovljeni temeljem novca koji nije ni očev ni majčin već njegov vlastiti koji je stekao, kako sam kaže, osobnim „trudom,

183 Katekizam Katolicke crkve, 276-277.

184. Prvi testamentarni legati za spas duše (pro remedio animae) se pojavljuju u 13., a ustalili su se u 14. stoljeću

(Žak Le Gof [Jacques Le Goff], Nastanak čistilišta, Sremski Karlovci - Novi Sad 1992., 299). O temi pobožnih legata hrvatska historiografija je uglavnom pisala na primjerima iz srednjovjekovne Dalmacije. Najopsežnija je i ujedno najrecentnija studija o toj temi u Hrvatskoj u autorstvu Zorana Ladića (Last will:passport to heaven. Urban last wills from late medieval Dalmatia, Zagreb 2012., posebno o historiografiji 23-52), a Istra od 16. do 18. st. na tu je temu obrađivana pokojim člankom ili njegovim dijelom u zadnjih petnaestak godina (Elvis Orbanić, „Pobožnost i društveni ugled malog čovjeka u perspektivi buzetskih oporuka s kraja srednjega vijeka“, I. Istarski povijesni biennale, zbornik radova, ur. Robert Matijašić, Poreč 2005., 195-208; isti, „Prilog poznavanju društvenog i vjerskog života u Labinu prve polovice 16. st.“, Raukarov zbornik. Zbornik u čast Tomislavu Raukaru, ur. Neven Budak, Zagreb 2005., 457-478; Elena Uljančić-Vekić, „Prilog proučavanju djelovanja porečke franjevačke zajednice od druge polovice 17. do prve polovice 18. stoljeća“, I. istarski povijesni biennale, 133-138; Elvis Orbanić, „Sacerdotes, iudices i notarius u Poreču 16. stoljeća - Društveno posredništvo na primjeru oporuka“, II. Istarski povijesni biennale, zbornik radova, ur. Neven Budak, Poreč 2007., 77-89; isti, „Oporučna pobožna praksa u Buzetu sredinom 16. stoljeća“, Buzetski zbornik, 38, 2011., 69-82; Igor Eterović - Ivana Eterović, „Devet lovranskih oporuka iz druge polovice 18. stoljeća: povijesna i jezična analiza, Histria, 3, 2013., 91-94; Samanta Paronić, ,Ulomci iz labinske prošlosti: prilog poznavanju društvenoga i religioznoga života“, Croatica Christiana periodica, 77, 2016., 109-127.)

185 ....ch'essendo fatto il testam(en)to ordinato, ed instituito ad pias causas... (ŽAP, Oporuka, 10.).

$186 \mathrm{Na}$ ist. $\mathrm{mj}$.

187 ŽAP, Oporuka, 5-7. 
mukom i znojem“. ${ }^{188}$ Duhovna potka ove Gausove poruke daje se prepoznati u učenju sv. Ivana Kasijana, crkvenoga oca, koji će tumačeći sv. Pavla napisati: „Dajući primjer ljubavi prema radu, ujedno poučava kako je bolje pomagati potrebitima dajući od onoga što je stečeno znojem, nego od onoga što je na neki drugi način došlo u naše ruke.“189

Na pitanje u kojoj su mjeri Gausovi oporučni izrazi pobožnosti bili svojstveni dobu i staležu kojem je pripadao, a koliko su bili odraz njegove autentične osobnosti i životne usmjerenosti nije jednostavno odgovoriti. Posve je nedvojbeno da testamentarne pobožnosti nisu isključivo odraz konvencija svojega doba.

\section{a) Preporučivanje duše}

Petar Antun Gaus je najprije preporučio svoju dušu Svemogućem Bogu, Blaženoj Djevici Mariji, svetome Petru i cijelom nebeskom koru te njegovim ostalim zaštitnicima da bi se zauzeli pred Stvoriteljem za njegovu dušu. ${ }^{190}$ Uvodni odlomak oporučnoga preporučivanja, svojevrsnoga molitvenog zaziva, bila je uobičajena praksa u oporukama srednjega i ranoga novog vijeka pa tako i početka 18. stoljeća. ${ }^{191}$ Vrlo je slično učinio jedan od Gausovih prethodnika na Katedri sv. Nicefora, biskup Raunnoch, ${ }^{192}$ suvremenik mu pulski biskup Bottari, ${ }^{193}$ ili primjerice također mu suvremenik, biskup Skradina Civalelli. ${ }^{194}$ Stvoritelj i Blažena Djevica Marija su redovito prvi koje se spominje, kao što je redovit i kraj preporučivanja u zazivu cijeloga nebeskog kora ili kumulativno svih svetica i svetaca. Stanovita raznolikost se odražava u središnjem

188 ...li quali (legati pii, op. E. O.) sono fatti à maggior gloria di Dio, e solievo dell anime purganti, dovendosi sapere da ciascheduno, che il danaro, con cui si sono instituiti predetti legati pij non sia ne paterno ne materno, mà bensì dal med(esi)mo mons(igno)r ill(ustrissi)mo e r(everendi)ssimo testatore conquistato con fatiche, stenti, e sudori... (ŽAP, Oporuka, 10.).

189 Ivan Kasijan, Duhovni boj s osam glavnih strasti, prema Filokaliji priredile Brigita Peček i Sonja Tomić, Zagreb 2013., 77 .

190 ŽAP, Oporuka, 2.

191 Istraživanje commendatio na primjeru 432 testamenta dviju kalabrijskih biskupija od 17. do 19. st. iznijelo je postojanje takvih zapisa: $88 \%$ u 17. st., $97,3 \%$ u 18. st., a 53,4\% u 19. st. Francesco Gaudioso, „Devozioni, intercessori e mediazione notarile. Problemi e prospettive di ricerca“, Ordini religiosi, santi e culti tra Europa, Mediterraneo e Nuovo Mondo, volume II, a cura di Bruno Pellegrino, Galatina 2009., 393; u hrvatskoj historiografiji vidi npr. poglavlje „Formula preporuke duše (commendatio animae) u rapskim oporukama“ u: Zrinka Novak, Pobožnost stanovništva rapske komune u drugoj polovici 16. stoljeća, doktorska disertacija, Sveučilište u Zagrebu, 2018., 96-99.

192 Elvis Orbanić, „Andrea Daniel di Raunnoch kao pićanski biskup (1670. - 1686.)“, Problemi sjevernog Jadrana, 18, 2020., 55 .

193 Giovanni Radossi, „Il testamento di monsignor G. M. Bottari 'vescovo meritissimo di Pola’ (1695-1729)“, Atti del Centro di ricerche storiche di Rovigno, 28, 1998., 558.

194 Lovorka Čoralić, „Oporuka skradinskog biskupa Grgura Civalellija iz 1713. godine“, Croatica Christiana periodica, 27, 1991., 139. 
dijelu molitvenoga zaziva, koji je odraz naročitoga osobnog izbora, u ovom slučaju oporučnoga, poimeničnoga spominjanja svetaca i ostalih nebeskih, poput anđeoskih, zaštitnika.

\section{b) Mise zadušnice}

Biskup određuje, kako u Pićnu, tako i u rodnoj mu Rijeci slavljenje mnogobrojnih misa koje imaju biti od pomoći njegovoj duši. Kroz te narudžbe sjetio se i drugih pokojnika, a posebno još dviju duša čija nam se imena ne otkrivaju. Financijske izdatke ove vrste će riješiti, kako ćemo pokazati, gotovim novcem i jednom nekretninom.

U tu svrhu katedralnom kaptolu Pićna ostavio je šezdeset škuda s obvezom služenja četiriju pjevanih misa unutar godine i to u kvatrenim tjednima perpetuis temporibus. Zbornom kaptolu Rijeke je ostavio stotinu dukata s obvezom slavljenja četiriju pjevanih misa unutar godine, također u kvatrenim tjednima perpetuis temporibus. Sve je to odredio uz uvjet da bude pokopan u Rijeci, u protivnom ovaj legat i obaveza trebao je prijeći na Pićan. ${ }^{195}$ Prema popisu imovine Pićanskoga kaptola iz 1743. proizlazi da je pićanski kanonik Matija Stuva služio naručene mise. Spomenuti novac kaptol je uložio kod Ivana Petra Tudorovića u Rijeci. ${ }^{196} \mathrm{Na}$ taj je način glavnica ostala netaknuta, a naručene pjevane mise su služene temeljem dobivenih kamata na prve petke u svakom godišnjem dobu. ${ }^{197}$ Nadalje, tražio je da se odmah nakon smrti čitaju tihe mise i to njih dvije tisuće, s time da svaka mora biti plaćena jednom lirom, kako je običaj u Pićnu. ${ }^{198}$ Kodicilom je definirao detalje. Za te dvije tisuće misa koje je odredio da se slave kao pomoć njegovoj duši naložio je da njih tisuću slave kanonici i svećenici Pićna, a drugih tisuću kanonici i svećenici u Rijeci, i to što je prije moguće. ${ }^{199}$

Nećaku Petru Tudoroviću ostavio je vinograd pokraj Sv. Nikole ${ }^{200}$ na prostoru Rijeke koji je biskup kupio od nasljednika pokojnoga riječkog arhiđakona Calucija. Nećak je imao zadatak naručivati svakoga mjeseca jednu misu perpetuis temporibus za pomoć biskupovoj duši. Ako taj nećak umre bez

195 ŽAP, Oporuka, 3.

196 Tullio Vorano, „I beni del capitolo di Pedena nei secoli XVII e XVIII“ (dalje: „I beni del capitolo di Pedena“), Atti del Centro di ricerche storiche di Rovigno, 27, 1997., 637, 639, 641.

197 Alojz Štoković, „Posjedovni odnosi u Pićanskoj biskupiji od XVI. do sredine XVIII. stoljeća“ (dalje: „Posjedovni odnosi“), Pićanska biskupija i Pićanština, 57.

198 ŽAP, Oporuka, 3.

199 ŽAP, Kodicil, B.

200 Kapela sv. Nikole je bila smještena na uzvisini riječke poljane Burgstaller te je pripadala augustincima. U njoj se misilo već u 14. stoljeću. Srušena je 1788. godine. Kobler, Memorie II, 149. 
potomstva, što je moguće jer prilikom sastavljanja oporuke još nije bio u braku, ${ }^{201}$ spomenuti vinograd ima naslijediti također biskupov nećak Nikola Andrija Tudorović, a nakon njegove smrti dobivaju ga kćeri biskupove sestre udovice Tudorović te njihovi nasljednici in perpetuum s istom obvezom naručivanja mjesečne mise. ${ }^{202}$

Kanoniku Josipu Tudoroviću (Giuseppe Tudorovich) ostavio je stotinu kranjskih forinti da se sjeti u svojim misama duše pokojnoga biskupa. ${ }^{203}$ Kodicilom je dodatno naručio slavljenje dvije tisuće tihih misa da se služe za više pokojnih. Svaka ima biti plaćena jednom lirom. Zatražio je i da se slavi pet stotina misa za jednoga pokojnog laika i pet stotina misa za jednoga pokojnog svećenika, ne preciziravši o kojim se osobama radi. ${ }^{204}$

Gaus je, što kroz oporuku, što kroz kodicil, naručio preko pet tisuća misa za spas vlastite duše.

\section{c) Dobra djela i molitve za pokojnikovu dušu}

Biskup u svojim legatima u više navrata i na više načina sjedinjuje dobra djela i molitve. U tu je svrhu odredio poveću količinu novca. Tako je nećaku svećeniku Nikoli Tudoroviću ostavio 150 forinti s obvezom da čini dobra djela s nakanom na pomoć biskupovoj duši. ${ }^{205}$ Biskup Gaus je u tom smislu uključio i franjevce kapucine, koji su u Rijeku došli početkom 17. st. te su se isticali karitativnim radom, naročito hraneći prosjake. ${ }^{206}$ Zasigurno je potaknut takvim njihovim pastoralnim usmjerenjem i humanitarnom angaŽiranošću ostavio ocima kapucinima samostana u Rijeci šezdeset dukata kako bi mogli pomoći njima bližnje siromahe te da se sjete pokojnika u misama i molitvama. ${ }^{207}$ Kodicilom je odredio da se dvanaest siromašnih prosjaka obuče u točno određenu tkaninu s time da mole za pokoj njegove duše. ${ }^{208}$ Ostavio je dodatnih 100 forinti da njegov nasljednik rasporedi siromasima odmah nakon njegove smrti, a da oni mole Boga za oporučiteljevu dušu. ${ }^{209}$

201 Petar Antun Tudorović će imati izvanbračnu kćer s Ivanom Mazunić 1710. (HR-DARI-0275, Matična knjiga krštenih Rijeka [1706. - 1720.], 20. ožujka 1710.). Oženit će se 1715. Franjicom de Derano (HR-DARI-0275, Matična knjiga vjenčanih Rijeka [1706. - 1720.], knjiga 419, 22. srpnja 1715.). Valja upozoriti na korespondenciju koju je biskup Gaus imao sa Svetom Stolicom zbog vjenčanja Petra Tudorovića (Archivio Apostolico

Vaticano, Lettere di vescovi e prelati, vol. 123, Il vescovo al Cardinale di Stato, Fiume, 20. srpnja 1714., 616-619) 202 ŽAP, Oporuka, 3-4.

203 Isto, 8.

204 ŽAP, Kodicil, B.

205 ŽAP, Oporuka, 5.

206 Kobler, Memorie I, 104-105.

207 ŽAP, Oporuka, 9.

208 ŽAP, Kodicil, C.

209 ŽAP, Oporuka, 8-9. 
Svakoj od četiriju neudanih kćeri svojega pokojnog brata Ivana Karla ostavio je 100 kranjskih forinti, s time da se sjete moliti Boga za pomoć biskupovoj duši. Nećaku Josipu Gausu oporukom je ostavio 100 kranjskih forinti koje mu imaju biti uručene onoga dana kada se zaredi ili se odluči na vojnu službu, s time da se sjeti moliti Boga za pomoć biskupovoj duši. ${ }^{210}$ Kodicilom je izmijenio oporuku utoliko što je zatražio da se nećaku taj iznos isplati samo ukoliko postane pavlinski redovnik, na što se biskup obvezao ocima pavlinima u Svetom Petru u šumi. ${ }^{211}$

Svakoj od triju nećakinja iz braka Ivana Šimuna i Viktorije Tudorović, njegove sestre i šogora, ostavio je 200 kranjskih forinti, s time da se sjete moliti Boga za njegovu dušu. Svojoj sestri udovici Katarini Zanchi darovao je jedan zlatni prsten u vrijednosti pet dukata i još jedan zlatni prsten jednake vrijednosti svojoj drugoj sestri Suzani, udovici Ernesta Spingarolija, s time da se sjete moliti Boga za njegovu dušu. ${ }^{212}$

Pićanskom kanoniku Jakovu de Vicchu kodicilom je naknadno ostavio 50 dukata da se sjeti njegove duše. ${ }^{213}$

Glavna nasljednica je obavezna potrošiti na siromahe i u pobožne svrhe prema vlastitom nahođenju sve što će ostati nakon što se plate pobožne ostavštine navedene $\mathrm{u}$ oporuci. ${ }^{214}$

\section{d) Utemeljitelj crkvenoga beneficija}

Biskup Gaus je oporukom ustanovio crkveni beneficij ad pias causas s obvezom četiriju tihih misa svakoga tjedna perpetuis temporibus koje je naložio služiti na oltaru sv. Antuna Padovanskoga u riječkoj zbornoj crkvi. Za tu nakanu ostavlja 2000 kranjskih forinti, što trebaju biti dane u sigurne ruke ili riječkom Monte di pietà ${ }^{215}$ ili riječkoj Općini, s obvezom točne isplate svake godine beneficijara sa šest posto. Odredio je da taj beneficij dobije njegov nećak i svećenik Nikola Andrija Tudorović, a nakon smrti toga nećaka neka beneficij primi neki sin pokojnoga brata Ivana Karla Gausa. Tu je postavio uvjet da taj svećenik ne smije biti riječki kanonik, čak ni u slučaju da se odrekne kanonikata ne bi mogao dobiti taj beneficij. Biskup

210 Isto, 7-8.

211 ŽAP, Kodicil, B.

212 ŽAP, Oporuka, 7-9.

213 ŽAP, Kodicil, C.

214 ŽAP, Oporuka, 10.

215 Riječki Monte di pietà osnovan je 1657. temeljem sredstava župnika Jeronima Stembergara (Stemberga). Kobler, Memorie II, 47; Luigi M. Torcoletti, Il Duomo vecchio di Fiume, Fiume 1932., 13. 
je u konkretnom slučaju zacijelo mislio na Eustahija Gausa, svojega nećaka koji je 1712. postao kanonikom pa ga je tako isključio iz mogućnosti stjecanja toga beneficija. Dodatno je odredio da ako sinovi Ivana Karla iz spomenutoga razloga ne mogu primiti rečeni beneficij, to pravo prijeđe na sinove svećenike biskupovih sestara, no i u odnosu na njih ima prednost eventualni sin svećenik biskupova nećaka Petra Tudorovića. Gaus je za taj beneficij nabavio srebrni kalež, pliticu, misnicu i albu za nadarbenika. Sve će to biti predano beneficijaru nakon biskupove smrti. Ako se ne nađe svećenik iz njegove rodbine za taj beneficij, naložio je riječkoj općini da imenuje svećenika. ${ }^{216}$

\section{e) Biskup i bratovštine}

Gaus je kao ordinarij obavijestio Rim da na Pićanštini ima mnogo bratovština te da su posvećene Presvetom oltarskom sakramentu, Djevici Mariji, Svetoj krunici i raznim svecima. ${ }^{217}$ Prema dosad objavljenim vrelima možemo zapaziti da je na Pićanštini tijekom ranoga novog vijeka (do 1746.) bilo nazivom poznatih devet bratovštinskih udruženja: sv. Antuna Padovanskog, Duša u Čistilištu, Sv. krunice, sv. Marije, sv. Mihovila, sv. Nicefora, sv. Roka, sv. Stjepana i Tijela Gospodnjega. ${ }^{218}$ Njihovi se patroni preklapaju s onime što iznosi biskup Gaus.

Biskup se u svojoj oporuci sjetio i nekolicine bratovština koje su sve djelovale isključivo u Rijeci. ${ }^{219}$ Tako je bratovštini Tijela Gospodnjega, ${ }^{220}$ koja je djelovala u riječkoj zbornoj crkvi, ostavio 20 dukata s obvezom naručivanja jedne tihe mise godišnje na pomoć njegovoj duši.

Bratovštini de Bianchi, koja je također djelovala u zbornoj crkvi Rijeke vezana za oltar Bogorodice od Karmela, ${ }^{221}$ ostavio je također 20 dukata, $s$ time da ima zadaću moliti Boga za njegovu pokojnu dušu.

\footnotetext{
216 ... beneficio ecclesiastico perpetuo ad causas pias... ŽAP, Oporuka, 4-5.

217 Grah, „Izvještaji pićanskih biskupa“, 11.

218 Vorano, „I beni del capitolo di Pedena“, 668; Štoković, „Posjedovni odnosi“, 54, 56-57. Biskup Piccardi (1766. - 1785.) navest će da je nekoć na području Pićanske biskupije bilo 77 bratovština, ali da su u njegovo vrijeme kanonski ispravne samo bratovština Duha Svetoga i Presvetoga oltarskog sakramenta u Gračišću te ona Duha Svetoga i Svete krunice u Pićnu. Grah, „Izvještaji pićanskih biskupa“, 16.

219 Bratovštine se u Rijeci pojavljuju u 15. st. U Koblerovu popisu navedeno je tijekom 18. st. deset bratovština. Kobler, Memorie II, 153-155. Gausov kodicil nam otkriva postojanje bratovštine koja je posvećena sv. Antunu Padovanskom.

220 Postojala je još u 16. st. Kobler, Memorie I, 155.

221 Bratovština neobičnoga naziva de Bianchi se spominje i u matičnoj knjizi umrlih Rijeke na više mjesta, npr. 14. listopada 1762. (HR-DARI-0275, Matična knjiga umrlih Rijeka [1702. - 1765.], knjiga 475). Postojala je još početkom 17. st. Kobler, Memorie II, 157.
} 
I bratovštini Presvetoga križa smještenoj u crkvi sv. Vida, koju su osnovali isusovci 1656., ${ }^{222}$ ostavio je 20 dukata uz napomenu da se bratimi u svojim molitvama sjete pokojnoga biskupa. ${ }^{223}$

Kodicilom je ukazao na još jednu riječku bratovštinu. Bila je to bratovština sv. Antuna Padovanskoga, kojoj je ostavio 100 dukata iz čiste pobožnosti. ${ }^{224}$

Iako joj ništa ne ostavlja, u svojem testamentu Gaus spominje bratovštinu Bezgrješnoga začeća ${ }^{225}$ u Rijeci, kojoj je namirio dug svojega pokojnog brata Ivana Karla. ${ }^{226}$ Ta je inače bičevalačka bratovština specifična i po tome što su tijekom 17. st. njezini članovi mogli biti jedino plemići. ${ }^{227}$

Gausovo podržavanje bratovštinskoga djelovanja nedvojbeno izvire iz njegove svijesti o vrijednosti duhovnoga i uopće zaštitničkoga djelovanja takve vrste crkvenih zajednica.

\section{Biskupova imovina: pokretnine i nekretnine}

Obitelj Gaus je posjedovala kuću u Rijeci u kontradi svete Barbare i jedan vrt s kućom iza staroga lazareta, gdje se put sa stare ceste za Trst uspinje prema Škurinju. ${ }^{228}$ Taj je prema Kobleru „stari lazaret“ zapravo Lazaret sv. Karla Boromejskoga, dovršen 1724., koji se nalazio zapadno od grada, između Mlake i Potoka, ${ }^{229}$ tako da na tom području valja tražiti i tu drugu kuću obitelji Gaus. Svojemu nećaku Ksaveru Andriji Gausu biskup je oporučno ostavio očev i majčin dio koji mu je pripadao u tzv. velikoj kući u Svetoj Barbari, gdje je 1714. živjela obitelj Gaus. Istome nećaku ostavio je tri četvrtine vrta uz tu kuću. Biskup je svojedobno kupio od pokojne majke vinograd zvan Braida na području Rijeke ${ }^{230}$ te je i njega ostavio tome nećaku. Gaus je posjedovao i jednu cijelu kuću u Rijeci. Naime, dr. Ksaveru Gausu ostavio je kuću u kojoj je 1714. obitavao Francesco Bronzini, s time da potonjem treba vratiti 200 škuda prije nego se iseli te mu platiti i popravke koje je učinio u kući. Napo-

\footnotetext{
222 Kobler, Memorie II, 155.

223 ŽAP, Oporuka, 8.

224 ŽAP, Kodicil, C.

225 Bratovština Bezgrješnoga začeća osnovana je 1573. u Rijeci. Kobler, Memorie II, 158.

226 ŽAP, Oporuka, 7.

227 Kobler, Memorie I, 158.

228 Kobler, Memorie III, 163.

229 Marijan Bradanović, „Riječka luka kroz povijest izgradnje lazareta“, Luke istočnog Jadrana, zbornik Pomorskog muzeja Orebić, ur. Mithad Kozličić i dr., Orebić 2006., 248.

230 Izraz brajda je čakavski naziv za vinograd općenito. Na području Rijeke postojao je predio s vinogradima još 40-ih godina 17. st. toga naziva. Darinko Munić, „Riječki vinogradi 1775.“, Vjesnik historijskih arhiva u Rijeci i Pazinu, 29, 1987., 237, 243.
} 
menuo je da sve što je ostavio nećaku Ksaveru, on ne smije prodavati, kao ni njegovi nasljednici. ${ }^{231}$

Biskupov nećak i izvršitelj oporuke ${ }^{232}$ Ivan Josip de Marburg je od glavne nasljednice trebao dobiti umivaonik i srebrni vrč koji je uvijek sa sobom nosio njegov stric biskup. ${ }^{233}$ No, kodicilom mu je zamijenio tu ostavštinu pozlaćenom srebrnom zdjelicom. ${ }^{234}$

Kodicilom je nećaku Petru Tudoroviću ostavio umivaonik s velikim srebrnim vrčem, a nećaku Ksaveru Gausu manji umivaonik sa srebrnim vrčem. ${ }^{235}$ U kodicilu se sjetio i dvojice svojih bližih, zasigurno pićanskih suradnika. Tako je kleriku Antoniju Claiu ostavio 20 dukata zbog vjernoga služenja, kao što je i sakristanu Matiji Belcu ostavio šest dukata. ${ }^{236}$

Iz svega proizlazi da je sva nekretnina u vlasništvu Petra Antuna Gausa bila smještena u Rijeci, a sastojala se od dijela veće obiteljske kuće s pripadajućim dijelom vrta koje je naslijedio te jedne manje kuće, kao i dva vinograda koja je sam kupio. Iako nemamo neposrednih potvrda, skloni smo pretpostaviti da je biskup tijekom svojega boravka u Rijeci kao vlastiti smještaj odabrao upravo obiteljsku kuću u predjelu svete Barbare.

\section{Želje oko ukopa}

Biskup Gaus je izrazio želju da, ako ga smrt zatekne u Pićnu, bude pokopan u katedrali unutar uobičajene rake za biskupe, a ako se to dogodi u Rijeci, onda ima biti pokopan u zbornoj crkvi u novoj grobnici, za što se ima skrbiti njegova sestra Viktorija Tudorović. Naložio je da se u Rijeci, ako ga ondje snađe smrt, napravi nova nadgrobna mramorna ploča s obiteljskim grbom i sažetim natpisom. ${ }^{237}$ Odlazak s ovoga svijeta ga je, ipak, zatekao u Pićnu 22. travnja 1716., a sahranjen je ispred glavnoga oltara pićanske katedrale u biskupskoj grobnici. ${ }^{238}$

\footnotetext{
231 ŽAP, Oporuka, 5-6.

232 Uz pazinskoga kapetana Josipa de Marburga, kao izvršitelja oporuke Gaus je odabrao i riječkoga kanonika Josipa Tudorovića. ŽAP, Oporuka, 12.

233 ŽAP, Oporuka, 12.

234 ŽAP, Kodicil, B.

235 Isto, B-C.

236 Isto, C.

237 ŽAP, Oporuka, 2-3. Obiteljski grb Gausovih ovako opisuje Kobler: „un gallo rosso sopra un colle dorato, e di sopra dello scudo una visiera coronata, due ali e due pesci“. Kobler, Memorie II, 163.

238 Jelinčić, Knjiga ređenja u Pićnu, 17.
} 


\section{Zaključak}

Dosadašnja historiografija skromno se bavila ličnošću i djelovanjem pićanskoga ordinarija Petra Antuna Gausa. Oskudnost arhivskih vrela koja se dotiču Gausa zacijelo potpomaže takvomu stanju. Nakon pomnijega iščitavanja dosad pronađenih malobrojnih pisanih svjedočanstava o tome prelatu, nismo uočili neko znamenitije djelovanje koje bi ga izdignulo na razinu naročite izvrsnosti. Usporedimo li ga s drugim pićanskim biskupima, zamijetit ćemo da je Gaus bio najrevniji u povijesti te dijeceze u slanju relacija ad limina. Svakako posebnu pozornost zaslužuje sadržaj njegove posljednje volje, kao i podatak o njegovu, navodno, neraspadnutom tijelu.

Gausovi dokumenti, njegova oporuka i kodicil, kako smo pokazali, predstavljaju ga osobom izrazite pobožnosti i suosjećanja prema potrebitima. Naime, Gaus je što kroz oporuku, što kroz kodicil, naručio preko 5000 misa za spas duše, a značajna je sredstva ostavio i za pomoć siromasima. Iz tih se vrela iščitava i Gausova povezanost s Rijekom - gradom njegova rođenja, u kojem su mu bile smještene sve bilo naslijeđene bilo naknadno stečene nekretnine.

U prosudbi Gausova biskupskoga djelovanja treba naglasiti da ga je u njegovu pićanskom razdoblju pratila bolest, koja je očevidno toliko uznapredovala da će u svibnju 1710. zamoliti da mu se dodijeli koadjutor, čemu je Sveta Stolica udovoljila imenujući također jednoga Riječanina, Jurja Franju Ksaverskoga Marottija, na tu službu.

Smrt je Gausa zatekla u Pićnu 22. travnja 1716., a sahranjen je ispred glavnoga oltara pićanske katedrale u biskupskoj grobnici u kojoj je, prema pisanju pićanskoga kroničara i župnika Težaka, njegov leš pronađen 1811. u neraspadnutom stanju. Budući da je prošlo 210 godina od te konstatacije, držimo da bi bilo uputno nanovo otvoriti kriptu u nekadašnjoj pićanskoj katedrali, današnjoj župnoj crkvi Navještenja Blažene Djevice Marije, te obaviti kanonsku rekogniciju zatečenih tjelesnih ostataka. 


\section{Sažetak}

Pićanskom se biskupu Petru Antunu Gausu u dosadašnjoj historiografiji pridavalo malo pozornosti. Razlog tomu je zacijelo skromna sačuvanost dokumenata za razdoblje njegova biskupovanja. Njegova oporuka i kodicil jedini su sačuvani Gausovi opsežniji osobni dokumenti. Rođen je 1646. u riječkoj plemićkoj obitelji kao najstariji sin. Najizglednije je da se školovao kod isusovaca u rodnome gradu, da bi potom nastavio studije do akademskoga stupnja doktora teologije. Bio je župnik u Bolzanu, a potom od 1679. župnik u Rijeci. Tu će iste godine postati kanonik, natpop te od 1683. arhiđakon i vanjski vikar pulskoga biskupa za Riječki arhiđakonat. Za pićanskoga biskupa izabran je 1691., a od pape je potvrđen 9. ožujka 1693. godine.

Redovito je izvještavao Svetu Stolicu o stanju na području Pićanske biskupije. Pridržavao se propisa i u pogledu obavljanja dužnosti pastoralnih vizitacija. U biskupskom poslanju podjeljivanja svetih redova djelovao je ukupno 114 puta. Prihodi same biskupije, koja je brojila od oko 4000 do oko 6000 duša tijekom njegova upravljanja, bili su toliko mali da je s njima mogao preživjeti svega nekoliko mjeseci. Zbog svoje će bolesti 1713. dobiti koadjutora u osobi Jurja Franje Ksaverskog Marottija.

U privatnom je životu bio posebno blizak sa svojim bratom Ivanom Karlom, što se očitovalo kroz biskupovo pokriće troškova bratova liječenja i njegovih brojnih dugova. Školovao je i dva njegova sina, jednoga do stupnja doktora znanosti u Padovi. Naročito je bio vezan za nećaka Ksavera Gausa kojem je izvjesno omogućio prestižno školovanje, a i oporučno mu je ostavio zamjetan imetak. Kao glavnu nasljednicu, a zapravo osobu zaduženu da podijeli u nabožne svrhe svu preostalu imovinu, odredio je svoju sestru Viktoriju Tudorović. Osobito je bio povezan s Rijekom, gradom svojega rođenja, u kojem su bile smještene sve njegove nekretnine. Biskup Gaus je bio osoba izrazite pobožnosti i empatije. Naime, oporučno je naručio nekoliko tisuća misa za spas vlastite duše, duša nekih drugih osoba te novac za pomoć siromasima. Umro je u Pićnu 22. travnja 1716., a sahranjen je ispred glavnoga oltara pićanske katedrale u biskupskoj grobnici, u kojoj je njegov leš pronađen 1811. navodno u neraspadnutom stanju.

\section{"L'uomo che visse vita pia all'inizio del XVIII secolo". Contributo alla biografia di Pietro Antonio Gaus (1646 - 1716), vescovo di Pedena}

\section{Riassunto}

Fino ad oggi, il vescovo pedenese Pietro Antonio Gaus non ha goduto di grande attenzione da parte della ricerca storiografica. Il motivo ne deve essere l'esigua conservazione della documentazione datata al periodo del suo vescovado. Il suo testamento e il codicillo sono gli unici documenti personali più consistenti del lascito di Gaus che sono stati conservati. Nato nel 1646 in una famiglia nobile fiumana come figlio maggiore, è probabile che sia stato educato dai gesuiti nella sua città natale per proseguire poi con gli studi fino a raggiungere il titolo di dottore di teologia. Fu parroco a Bolzano e poi dal 1679 a Fiume. Lo stesso anno divenne canonico, arciprete e dal 1683 arcidiacono e vicario foraneo del vescovo polese per l'Arcidiaconato di Fiume. È stato eletto vescovo nel 1691 e confermato dal papa il 9 marzo 1693. 
Ha tenuto regolarmente informata la Santa Sede sulla situazione vigente nei territori della Diocesi di Pedena. Si è attenuto ai regolamenti anche sotto l'aspetto dell'adempimento agli obblighi delle visite pastorali. Da vescovo ha partecipato complessivamente 114 volte al conferimento dell'ordine sacro. Gli introiti della diocesi che sotto la sua gestione contava da circa 4000 a circa 6000 anime, erano talmente scarni che gli potevano permettere di viverci per alcuni mesi appena. A causa della sua malattia, nel 1713 gli fu attribuito un vescovo coadiutore nella persona di Giorgio Francesco Saverio Marotti.

Nella vita privata fu particolarmente legato al fratello Giovanni Carlo verso cui provava un forte affetto che risultava evidente dalla sua disposizione a coprire tutte le spese delle cure di cui il fratello necessitava come anche dei suoi numerosi debiti. Ha anche provveduto alle spese dell'educazione dei due figli del fratello, portandone uno fino al titolo di dottore di ricerca a Padova. Era particolarmente legato anche al nipote Saverio Gaus a cui ha garantito un'educazione di prestigio assicurandogli inoltre un notevole lascito testamentario. Quale sua erede principale designò la sorella Vittoria Tudorović, nominandola responsabile per la distribuzione dell'eredità restante destinata a scopi religiosi. Un legame particolare lo univa a Fiume, la sua città natale in cui erano collocati tutti gli immobili di sua proprietà. Il vescovo Gaus è stato una persona particolarmente devota ed empatica. Infatti, nel testamento chiede che vengano servite alcune migliaia di messe per la salvezza della sua e delle anime di altre persone mentre una parte del denaro era stata messa a disposizione per l'assistenza ai poveri. Morì a Pedena il 22 aprile 1716 e venne sepolto nella tomba vescovile davanti all'altare principale della cattedrale di Pedena. Nel 1811 venne qui ritrovata la sua salma in quello che fu, a quanto pare, un ottimo stato di conservazione.

\section{"A man who lived a pious life in the early $18^{\text {th }}$ century". Contribution to the biography of Peter Anton Gaus (1646 - 1716), the Bishop of Pićan}

\section{Abstract}

So far in historiography, little attention has been given to the Bishop of Pićan, Peter Anton Gaus. The reason for this is certainly the modest preservation of documents for the period of his episcopate. His will and codicil are the only more copious surviving personal documents left by Gaus. He was born in 1646 in a noble family in Rijeka as the eldest son. He was most likely educated by the Jesuits in his hometown, and then continued his studies to the academic degree of Doctor of Theology. He was pastor in Bolzano, and then from 1679 pastor in Rijeka. That same year he became canon, archpriest and, from 1683, archdeacon and associate vicar of the bishop of Pula for the archdeaconry of Rijeka. He was elected bishop of Pićan in 1691, and confirmed by the Pope on 9 March 1693.

He regularly reported to the Holy See on the situation in the area of the Diocese of Pićan. He also complied with the regulations regarding the performance of pastoral visits. He acted a total of 114 times in the episcopal mission of giving the Holy orders. The income of the diocese itself, which numbered from about 4,000 to about 6,000 souls during his reign, was so small that he could survive on them for 
only a few months. Due to his illness, in 1713 he received a coadjutor in the person of Giorgio Francesco Saverio Marotti.

In his private life he was particularly close to his brother Giovanni Carlo, which manifested itself through the bishop's coverage of the costs of his brother's treatment and his numerous debts. He also educated his two sons, one to the degree of Doctor of Science in Padua. He was especially attached to his nephew Saverio Gaus, to whom he certainly provided a prestigious education, and left him a notable fortune in his will. He appointed his sister Vittoria Tudorović as the main heiress, and in fact the person in charge of dividing all the remaining property for religious purposes. He was especially attached to Rijeka, the city of his birth, in which all his estates were located. Bishop Gaus was a person of outstanding piety and empathy. Namely, he bequeathed several thousand masses to be served to save his own soul, the souls of some other people, and money to help the poor. He died in Pićan on 22 April 1716, and was buried in front of the main altar of the Pićan Cathedral in the bishop's tomb, where his body was found in 1811, allegedly in an undecomposed state.

\section{Prilozi}

\section{Nekoliko napomena o prijepisu}

Dva dokumenta koja donosimo u prijepisu nalaze se pohranjena u Župnom arhivu u Pićnu. ${ }^{239}$ Formata su A4, pisana na papiru, željezno-galnom tintom. Radi se o prijepisima koje je 1743. načinio Marko Bančić, kapelan pićanske bratovštine Duša u Čistilištu, a ovjerio ih je Josip Antun Costanza, apostolski protonotar, župnik u Krbunama i kancelar biskupije.

Dokumenti su naknadno numerirani. U prijepisu oporuke i kodicila razriješene su sve kratice s time da su posebno naglašene okruglim zagradama. Razure koje su nastale rukom pisača izvornika, kao i priređivačke intervencije u oštećeni dio teksta označene su, sukladno Stipišićevoj uputi, uglatim zagradama. ${ }^{240}$ Velika i mala slova pisana su prema suvremenom talijanskom pravopisu. U manjem broju slučajeva intervenirano je i u interpunkciju prilagođavajući i nju današnjem čitatelju.

239 Župni arhiv Pićan (1643.-1786.). Biskupski i kaptolski spisi 2,8. I na ovome mjestu želimo zahvaliti župniku Pićna, preč. Antunu Kureloviću, na velikodušnoj susretljivosti prilikom istraživanja u župnom uredu. sačinjen sukladno uputama iz te knjige (178-179). 


\section{Prilog 1.}

\section{Oporuka}

(1)

Testamento

del monsig(no)r Gaus fù vescovo di Pedena.

(2)

\section{Copia}

Nel nome di Dio. Amen. Nell'anno corr(en)te della Sua S(antissi)ma Natività 1714. indiz(io)ne $7 \mathrm{ma}$ il giorno di lunedi li 17 del mese 7 embre fatto nella città di Pedena nel palazzo episcopale nella camara chiamata stuva alla presenza degl'infrascritti testimonij idonei, conosciuti a questo havuti, chiamati, e specialm(en)te pregati etc.

Constituito personalm(en)te avanti di me infras(cri)tto not(ar)o e testimonij sottos(crit)ti l'ill(ustrissi)mo e r(everendi)ssimo monsig(no)r Pietro Antonio Gaus d'Omperg, abbate di S(an) Giorgio in Canat, di s(acra) c(esarea) m(aestà) consigliere, d(otto)re della sacro santa teologia, sig(no)re di Gollagorizza, e ves(co)vo di Pedena etc. Quale, lodato il sig(no)r Iddio, san(n)o di mente, sensi, loquella, memoria, udito, ed intelletto volendo sintanto che gode la quiete nel corpo, e buona ragione nell'animo, provedere alla salute dell'anima sua, essendo à sig(nori)a ill(ustrissi)ma e r(everendi)ssima ben noto non essere cosa più certa della morte, ne cosa più incerta dell'hora della morte, hà voluto ordinare à me infras(crit)to pub(li)co imp(eria)le not(ar)o d'estender la presente sua ultima disposizione e volontà ò sia testamento nuncupativo in questa pub(li)ca forma etc.

E primieram(en)te sua sig(nori)a ill(ustrissi)ma e r(everendi)ssima hà raccomandato l'anima sua all'Onnipotente Iddio, Ottimo, e Massimo alla Beatissima Sempre Vergine, à san Pietro, ed à tutta la Corte Celestiale ed altri santi suoi prottettori, ed avvocati affine intervedessero apresso Sua Divina Maestà p(er) la salute dell'anima sua.

Il corpo poi lascia alla commune madre terra, da dove hebbe l'origine, e principio. Ordinando che in caso che il Sig(no)r Iddio lo levasse da questa all'altra miglior vita qui in Pedena, il suo corpo doppo che sarà separata l'anima, sia 
sepolto in questa cathedrale chiesa nella solita archa delli vescovi antecesori con quelli funerali accompagnato, che convengono al di lui Stato. Caso poi il Sig(no)r Iddio lo levasse dal mondo in Fiume sua patria, vuole, ed ordina, venga sepolto nella chiesa dell'insigne collegiata di Fiume nella sepoltura nuova di ragione della mol(to) ill(ust)re sig(no)ra Vittoria Tudorovich sua dilettissima sorella, situata nella medema Chiesa. Ordinando, li

\section{(3)}

venga fatta una lapida nuova di marmo con l'arma della sua casa, con l'inscrizione di qualche succinto epitaffio, con quel conveniente funerale, che appartiene al suo stato.

Item Jure legati p(er) amore, e benevolenza, e beneficio dell'anima sua, sua sig(nori)a ill(ustrissi)ma, e r(everendi)ssima lascia, e lega all'(!) venerabile Capitolo di questa cattedrale di Pedena scudi sessanta di lire dieci l'uno, dico scudi 60:- per li quali saranno obligati li signori canonici di celebrare quatro(!) messe cantate all'anno nella se[ttimana] delle quatro tempora per l'anima sua perpetius temporibus, cioè ogni quatro tempora una messa cantata. Item Jure legati lascia, e lega all'(!) venerabile Capitolo di Fiume ducati cento di sei lire l'uno, dico ducati 100:- coll'obligo di celebrare quatro(!) messe cantate annualm(en)te quatro(!) tempora dell'anno perpetuis temporibus per suffraggio della sua anima, mentre però si dasse il caso, che detto monsig(no)r l'ill(ustrissi)mo e r(everendi)ssimo testatore passasse da questa alla miglior vita in Fiume, et che il suo cadavere venisse sepolto in detta chiesa collegiata in Fiume, e non altrimente; se non al Capitolo, ove riposarà il suo corpo. Item vuole, et ordina sua sig(nori)a ill(ustrissi)ma, e r(everendi)ssima, che subito doppo la sua morte li vengono lette, e celebrate messe basse doimilla, dico 2000:- dovendo esser pagata cadauna messa con soldi venti, idest, lire una secondo il solito del paese.

Item Jure legati p(er) amore, e benevolenza lascia e lega all'(!) molto ill(ust)re sig(no)re Pietro Tudorovich suo dilettissimo nipote la vigna da S(an) Nicolò posta nel territorio di Fiume, comprata da sua sig(nori)a ill(ustriss)ma, e r(everendi)ssima dall'eredi di q(uonda)m sig(no)r archidiacono Caluci, e questa con tutte le sue ragioni, e giurisdizioni, abbezze, attinenze, e pertinenze, nissuna cosa esscluza, ne eccettuata acciò detto suo sig(no)r nipote si ricordi di far celebrare una messa al mese perpetuis temporibus p(er) suffraggio dell'anima sua, con condizione però, che se detto suo sig(no)r nipote morisse senza 


\section{(4)}

eredi /: il che Iddio non voglia :/ detta vigna deve godere il m(ol)to ill(ust)re r(everen)do sig(no)r Nicolò And(re)a Tudorovich suo diletissimo nipote, e poscia doppo la sua morte la debbono godere le figlie della sua sig(nor)a sorella ved(ov)a Tudorovich con li loro descendenti in perpetuum con sopra$\mathrm{d}($ et) to obligo.

Item Jure legati lascia, e lega alla molto ill(ust)re sig(nor)a Vittoria vedova Tudorovich sua dilettissima sorella fiorini mille dico F 1000:- li quali, li furono già consegnati, et esborsati da sua sig(nori)a ill(ustrissi)ma e R(everendi)ssima ipso vivente. Ordinando, che introvandosi trà le scritture qualche poliza, ò qual si sia nota debitoriale di sud(et)ta sig(nor)a Vittoria, ò chi per essa, o pure se da qualcheduno altro della Casa Tudorovich fatta l'avesse, il tutto vuole, e dichiara sia nullo, ed invalido, come fatto non fosse, havendo detto monsig(no)r ill(ustrissi)mo, e r(everendi)ssimo testatore rilasciato il tutto.

Item Jure legati il predetto monsig(nor)e ill(ustrissi)mo, e r(everendi)ssimo testatore instituisce addesso per all'hora un beneficio ecclesiastico perpetuo ad causas pias, con obligo di quatro(!) messe basse ogni settimana perpetuis temporibus, le quali doveranno essere dette all'altare di s(an) Antonio di Padova esistente nella chiesa dell'insigne collegiata di Fiume de requiem in quanto comportarà il tempo dell'anno secondo l'intenzione dell'ill(ustrissi)mo e r(everendi)ssimo monsig(no)r testatore: $\mathrm{p}$ (er) la fondazione di tal beneficio lascia sua sig(no)ria ill(ustrissi)ma, e r(everendi)ssima fiorini cragnolini due milla, dico F. 2000:- di L 4:10 l'uno. Ordinando che li sudetti due milla fiorini vengano dati all'interesse in mano di persone sicure, ò pure incorporati nel monte di pietà in Fiume, ò pure vengano dati in mani dell'ill(ustrissi)ma Communità di Fiume con tutte le dovute assicurazioni con obligo di esborsar pontualm(en)te al beneficiato ogni anno sei per cento. Il beneficio sud(et)to vuole, ed ordina l'habbia il $\mathrm{m}(\mathrm{ol})$ to ill(ust)re, e m(ol)to r(everen)do sig(no)r Nicolò And(re)a Tudorovich suo dilettissimo nipote, dovendo il medemo esser anteposto, e preferito à tutti, e dopo la sua morte resti il sud(et)to beneficio nella persona di qualche sacerdote figliuolo del q(uonda)m nobile suo sig(no) r fratello Gio(vanni) Carlo Gaus, con condizione però, che

(5)

detto sacerdote non sia canonico della collegiata, e se anche rinonciasse il canonicato non sia capace d'aver detto beneficio, mà bensi che detto beneficio 
possan godere li figli sacerdoti delle sorelle dell'(!) mons(igno)r ill(ustrissi)mo, e r(everendi)ssimo testatore, alle quali tutte però doverà esser preferito qualche figlio del sig(no)r Pietro Tudorovich suo dilettissimo nipote, mentre fosse sacerdote.

Si dichiara uleriorm(en)te più chiaram(en)te che se il sig(no)r Pietro Tudorovich suo dilettissimo nipote havesse qualche figlio sacerdote, questo sia preferito alli figli delle sorelle del mons(igno)r ill(ustrissi)mo, e r(everendi)ssimo testatore, e non ostante, che sua sig(nori)a ill(ustrissi)ma, e r(everendi)ssima non vuole, che veruno possa godere detto beneficio, mentre di già fosse canonico di Fiume, tutta volta si contenta, e vuole, che il m(ol)to ill(ust)re, e m(ol)to r(everen)do sig(no)r Nicolò Tudorovich sud(ett)o lo possa godere etiandio fosse canonico sine consequentia d'altri per tal effetto sua sig(nori)a ill(ustrissi)ma, e r(everendi)ssima hà di già proveduto del calice d'argento, patena, pianeta, ò sia casula, e camice per la celebrazione del beneficiato. Le quali cose doveranno esser consegnate doppo la sua morte al medemo.

Quando poi non si ritorivasse alcun sacerdote suo parente per il detto beneficio cada il Jus nominandi detto beneficiato all'ill(ustrissi)ma Communità di Fiume.

Item Jure legati, p(er) amore, e benevolenza lascia, e lega al sud(et)to sig(no)r $\mathrm{d}(\mathrm{on})$ Nicolò Tudorovich suo nipote fiorini cragnolini cento, e cinquanta dico F. 150:- affine si ricordi di far bene p(er) suffraggio dell'anima sua.

Item Jure legati per amore, affetto, e benevolenza lascia, e lega all'ecc(elentissi) mo sig(no)r d(otto)re Saverio And(re)a Gaus suo dilettissimo nipote tutta la porzione si paterna, che materna, che s'apartiene à sua sig(nori)a ill(ustrissi) ma, e r(evrendi)ssima nella casa grande, dove al presente habitano li sig(no) ri Gaus posta in Fiume nella Contrada di S(anta) Barbara, così pure al sud(et) to Sig(nor)e D(otto)re Saverio lascia trè parti dell'orto contiguo alla sud(et) ta casa cioè due parti comprate da sua sig(nori)a ill(ustrissi)ma e r(everendi) ssima con dinaro proprio, come consta nelle ricepute, ed la terza come quella li proviene dall'eredità. Item al med(esi)mo sig(no)r d(otto)re Saverio lascia, e lega la vigna detta Braida posta

\section{(6)}

nel teritorio di Fiume, dal mons(ignor) ill(ustrissi)mo, e r(everendi)ssimo testarore comprata dalla defonta sua sig(nor)a madre, òpure data à godere per fiorini cinquecento come consta nelle scritture. Di più lascia; e lega al giad(et)- 
to $\operatorname{sig}$ (nor)e d(otto)re Saverio Gaus la casa, dove al presente habita il sig(no)r Francesco Bronzini con pato e condizione, che restituir debba al sud(et)to sig(no)r Bronzini scudi duecento di dieci lire l'uno con pagamento delli miglioramenti, mentre l'avesse fatto detto Sig(no)r Bronzini. Ordinando, che il medemo resti in pacifico possesso della casa sino la restituzione delli sud(et)ti scudi duecento, dati dall'ill(ustrissi)mo monsig(no)r testatore goder a godere dal giad(et)to sig(no)r Bronzini. Ordinando, e volendo assolutam(en)te che detto sig(no)r suo nipote d(otto)re Saverio non possa ne vendere, ne alienare detta casa, ne tampocco la Braida, mà che in perpetuum sia di lui, e della sua successione cioè figli, e figlie legitime, e che ne tampocco questi habbino mai la facoltà di vendere, ò alienare sud(et)ta casa, Braida, e la porzione della casa grande, ed orto ad essa contiguo, ma che in mancanza detti beni stabili con casa grande, e la casa minore habitata dal sig(no)re Bronzini, Braida etc. debbono decadere, e pervenire alli più propinqui parenti eredi dell'ill(ustrissi)mo e r(everendi)ssimo testatore coll'istesso obligo, e condizione, che mai si possono vendere, ne alienare pred(et)ti beni stabili qui specificati.

Item Jure legati lascia, e lega al sud(et)to ecc(elentissi)mo s(igno)r d(otto)re Saverio Gaus li ducati trecento stati imprestati dall'ill(ustrissi)mo, e r(everendi)ssimo monsig(no)r testatore al q(uonda)m sig(nor)e Gio(vanni) Carlo Gaus di lui fratello nel tempo, che sposò la sua figliuola Elisabetta con il sig(no)r Francesco de Slemberg, qual dinaro ordina si faci esso s(igno)r $\mathrm{d}$ (otto)re restituire dall'eredi del q(uonda)m suo sig(no)r padre Gio(vanni) Carlo sud(et)to.

Item Jure legati lascia, e lega al med(esi)mo sig(no)r d(otto)re Saverio Gaus scudi cento stati imprestati dall'ill(ustrissi)mo, e r(everendi)ssimo monsig(no)r testatore al pred(et)to q(uonda)m suo fratello Gio(vanni) Carlo Gaus, li quali li dovevano essere restituiti dall'eredi q(uonda)m sig(no)r Gio(vanni) Carlo sud(et)to.

Item Jure legati lascia, e lega al più volte nominato sig(no)r d(otto)re

(7)

Saverio scudi settanta quatro(!) dal monsig(no)r ill(ustrissi)mo, e r(everendi)ssimo testatore pagati, ed esborsati al sig(no)r Francesco Redinger chirurgo di Fiume per debito contrato dal q(uonda)m Sig(no)r Gio(vanni) Carlo Gaus, e sua sig(nor)a consorte, come aparisca dalla ricevuta. Item al medemo sig(no)r $\mathrm{d}$ (otto)re Saverio lascia ducati cinquanta pagati, ed esborsati dal mons(igno)r 
ill(ustrissi)mo, e r(everendi)ssimo testatore per il debito dovuto dal q(uonda)m sig(no)r Carlo sud(et)to all'ecc(elentissi)mo sig(no)r d(otto)re medico Rocchi come consta nella ricevuta, dovendosi questi, e l'altri sopra(de)tti dinari esborsati, e pagati per il q(uonda)m sig(no)r Gio(vanni) Carlo Gaus sud(et)to restituire dagl'eredi suoi di detto sig(no)r Gio(vanni) Carlo.

Item Jure legati lascia, e lega al med(esi)mo sig(no)r d(otto)re Saverio Gaus ducati trecento dal monsig(no)r ill(ustrissi)mo, e r(everedni)ssimo testatore pagati, et esborsati alla capella dell'Immacolata Concezione essistente in Fiume per il debito dovuto dal più volte nominato q(uonda)m sig(no)r Gio(vanni) Carlo Gaus, come consta dalla riceputa di detta capella, o sia confraternità dell'Immacolata Concezione. Item lascia al sud(et)to sig(no)r d(otto) re Savierio fiorini cento cragnoilini pagati ed sborsati da sua Sig(nori)a ill(ustrissi)ma, e r(everendi)sssima alle madri monache per il debito contratto dal detto q(uonda)m suo sig(no)r fratello Gio(vanni) Carlo. Di più lascia, e lega al $\operatorname{sud}($ et)to $\operatorname{sig}($ no)r d(otto)re Saverio suo dilettissimo nipote fiorini cento cragnolini pagati, ed sborsati dal monsig(no)r ill(ustrissi)mo, e r(everendi)ssimo testatore per il debito dovuto dal q(uonda)m sig(no)r suo fratello Gio(vanni) Carlo Gaus al q(uonda)m s(ignor) Zilio Zamarchi speciale di Fiume, il qual danaro delle soprad(et)te summe si dovrà far restituire dall'Eredi del q(uonda)m sig(no)r Carlo Gaus. Ordinando, e volendo sua sig(nori)a ill(ustrissi)ma, e r(everendi)ssima ch'in caso il sud(et)to sig(no)r d(otto)re Gaus n(on) potesse esser sodisfatto $\mathrm{p}(\mathrm{er})$ li legati di sopra specificati dall'eredi del q(uonda)m sig(no)r Gio(vanni) Carlo Gaus suo padre, e respettivam(en)te fratello dell'ill(ustrissi)mo, e r(everendi)ssimo monsig(no)r testatore debba lasciar in tal caso imperturbato il suo erede qui sotto nominato senza punto molestato sotto qualssisia pretesto, altri(men)te in tal caso addesso per all'hora vuole, e co(m)manda l'ill(ustrissi)mo, e r(everendi)ssimo mons(igno)r testatore sud(et)to esser deceduto o privo esso s(igno)r d(otto)re Saverio Gaus d'ogni legato, e lasciado.

Item Jure legati lascia, e lega alle quattro figliuole del q(uonda)m sig(no)r Gio(vanni) Carlo Gaus di lui fratello hora esistenti senza marito, per caduna

(8)

fiorni ciento Cragnolini, affine si ricordino pregar Iddio per suffraggio dell'anima sua.

Item Jure legati lascia, e lega al s(pettabi)le Giuseppe Gaus suo dilettis- 
simo nipote fiorini cragnolini cento, li quali li doveranno esser esborsati nel tempo del giorno che farà professione in qualche religione, o pure al tempo che volesse abraziare il(!) stato militare, acciò si ricordi di pregar Iddio p(er) l'anima sua.

Item Jure legati lascia, e lega alle trè sue nipoti figliuole procreate col q(uonda)m s(pettabi)le Gio(vanni) Simone, e Vittoria Tudorovich sua sorella, e cognato fiorini cragnolini due cento $\mathrm{p}(\mathrm{er})$ caduna $\mathrm{p}(\mathrm{er})$ una volta tantu(m), acciò si ricordino pregar Iddio p(er) l'anima sua.

Item Jure legati lascia, e lega al r(everendi)ssimo mons(igno)r can(oni)co Giuseppe Tudorovich fiorini cragnolini cento $\mathrm{p}(\mathrm{er})$ una volta tantu(m) acciò sia memore nelli suoi santi sacrificij di sufraggare l'anima dell'(!) monsig(no)r ill(ustrissi)mo ves(co)vo testarore.

Item Jure legati lascia, e lega alla veneranda confraternità di Corpus D(omi)ni erretta in Fiume nella chiesa colleggiata $\mathrm{p}(\mathrm{er})$ una volta tantu(m) ducati venti di lire sei l'uno con l'obligo alla med(esi)ma Confraternità di far celebrare $\mathrm{p}(\mathrm{er})$ petuis temporibus una messa bassa all'anno per suffraggio dell'anima sua. Item Jure legati lascia, e lega alla veneranda confraterna de Bianchi erretta nella sud(et)ta colleggiata chiesa di Fiume $\mathrm{p}(\mathrm{er})$ una volta tantu(m) ducati venti di lire sei l'uno, acciò detta Confraterna si ricordi di pregar il S(igno)r Iddio p(er) l'anima sua.

Item Jure legati lascia, e lega alla confraterna del S(antissi)mo Crocefisso di S(an) Vito in Fiume p(er) una volta tantum ducati venti di lire sei l'una, pregando li sig(no)ri confratelli d'aver memoria nelle loro sante orationi dell'anima dell'ill(ustrissi)mo, e r(everendi)ssimo mons(igno)r testatore.

Item Jure legati lascia, e lega fiorini cento quali doverano essere

(9)

distribuiti alli poveri dal suo erede subito doppo la sua morte acciò quelli preghino Iddio per l'anima sua.

Item Jure legati lascia, e lega alla dilettissima sua signora sorella Cattarina ved(ov)a Zanchi un'annello d'oro di ducati cinque, ed un altro annello d'oro parim(en)te di ducati cinque alla sig(nor)a Susana ved(ov)a Spingaroli sua dilettissima sorella $\mathrm{p}(\mathrm{er})$ puro amore, affetto, e benevolenza, acciò si ricordino pregar il S(ignor)e Iddio p(er) l'anima sua.

Item ad altri suoi s(ignor)i parenti lascia, e lega il suo perpetuo affetto, havendoli sempre teneram(en)te amati. 
Item Jure legati lascia alli $\mathrm{m}(\mathrm{ol})$ to $\mathrm{r}($ everendi) $\mathrm{p}$ (adri) capucini del convento di Fiume $\mathrm{p}(\mathrm{er})$ una volta tantu(m) ducati sessanta di lire sei l'uno, affine si possino provedere di qualche bisognevole come poverò à loro più proprio, pregandoli haver raccomandata l'anima sua nelli loro s(anti) sacrificij, ed orazioni.

In tutto poi, e per tutto il sopra(dett)o mons(igno)r ill(ustrissi)mo, e r(everendi)ssimo vescovo testarore instituisce, nomina, dischiara e crea per il suo u(niversa)le e legitimo erede (...) la m(ol)to ill(ust)re sig(no)ra Vittoria ved(ov)a Tudorovich sua dilettissima sorella. Instituendola, dichiarandola, nominandola, e creandola $\mathrm{p}(\mathrm{er})$ tale in tutti e caduni suoi beni, ed effetti, mobili, e stabili, presenti e venturi, ovunque essistenti, niente escluso, riprovato, ne eccettuato ordinando, e volendo, e commandando, che per tale venghi ricognosciuta, e riconoscersi debba, obligando la pred(ett)a sua sig(nor)a erede di sodisfare inmediatam(en)te li sudetti, ed in questo testam(en)to nominati, legati, e lascidi col danaro inprestato à diversi sopra li pegni che tiene in cassa, ed oltre del danaro di detti pegni debba servirsi ancor del med(esi)mo ill(ustrissi)mo, e r(everendi)ssimo testat(or)e imprestato sopra semplice instrom(en)to ò riceputa fatta col proprio pugno delli debitori, li quali istrom(en)ti si trovano in una scatola separata. E volendo alcuno à questa sua disposizione, ed ultima volontà fatta con animo deliberato

\section{(10)}

assoluta volontà opporsi, s'intende citato avanti il tribunale di Dio, come disturbatore inquieto, ed impeditore dei legati pii, li quali sono fatti à maggior gloria di Dio, e solievo dell'anime purganti, dovendosi sapere da ciascheduno, che il danaro, con cui si sono instituiti predetti legati pii non sia ne paterno ne materno, mà bensì dal med(esi)mo mons(igno)r ill(ustrissi)mo e r(everendi)ssimo testatore conquistato con fatiche, stenti, e sudori, tanto più che non hà mancato di beneficar amor vivente il q(uonda)m suo sig(no)r fratello Gio(vanni) Carlo Gaus; con somme considerabili ed effettivo danaro p(er) puro affetto, e massime p(er) li studij delli due suoi sig(no)ri figliuoli, li quali ascendono alla summa di mille ducento ducati, havendo l'uno mantenuto trè anni in Germania, e l'altro similm(en)te trè cioè due in Gorizia ad un'anno in Padova, oltre il dotorato(!) di Padova del primo, quale costò quatrocento e cinquantacinque ducati.

Aggiongesi anco p(er) esser esso volere, e comando dell'ill(ustrissi)mo, e r(everendi)ssimo m(onsi)g(no)r testatore, ch'essendo fatto il testam(en)to ordinato, 
ed instituito ad pias causas, che detta sua sig(nor)a erede debba contentarsi con li mille fiorini cragnolini gia anticipam(en)te datili sperando, che la medema, come più volte promise à sua sig(nori)a ill(ustrissi)ma e r(everendi)ssima, non pretenderà altro delle sue sostanze, mà bensì tutto quello, ch'avanzerà, ò avanzar potesse, detratti li legati li debba spender à suo piacere detta sua sig(nor)a erede à quelli poveri, che li pareranno più bisognevoli, è in altre opere pie come li parerà più proprio, fidandosi esso mons(igno)r ill(ustrissi)mo, e r(everendi)ssimo testatore nella di lei delicata conscienza, che il tutto esequirà fedel(men)te ne vuole pred(et)to ill(ustrissi)mo, e r(everendi)ssimo mons(igno)r testatore che la sua $\operatorname{sig}($ nor)a erede fosse obligata ne sforzata da qualsi sia tribunale, o da chi si sia altro di render minimo conto della sua administrazione, e dispensa del soprad(ett)o danaro, annulando con il presente, e cassando(!) qualsisia anteriore altro testam(en)to e qualunque donazione, che quì non è contenuta; quando sud(et)to mons(igno)r ill(ustrissi)mo, e r(evrendi)ssimo testatore di non aver fatto mai alcuna donazione ad alcuno, ò sia inter vivos, opure

\section{(11)}

causa mortis, e se pure qualche duno fosse tanto temerario, ed ingiusto, che volesse prodarre qualche donazione del mons(igno)r ill(ustrissi)mo, e r(everendi)ssimo testatore mai sogniata, la dichiara per falsa ed illegitima senza alcun vigore, dovendo il medemo come falsario esser castigato severam(en)te dalla giustizia divina e temporale.

Aggiongesi anco, che l'ill(ustrissi)mo, e r(everendi)ssimo mons(igno)r testatore per sgravio della sua conscienza dichiara esser la verità, ch'esso lui mai abbia condesceso che la metà della Braida sia data, ed usurpata dalla sig(nor)a Antonia Paus sua sorella, come improprieta, ma che solam(en)te potesse iususfruttuare quella parte, che fù assegnata in detta Braida per il di lei mantenimento con donno dell'ill(ustrissi)mo mons(igno)r testatore, poiche esso innanzi usufruttuava tutta la Braida, mà s'hà contestato per carità di ceder la metà delli usufrutti alla medema senza alcun pregiudizio del q(uonda)m suo sig(nor) fratello Gio(vanni) Carlo, e delli di lui sig(no)ri figlioli, e nell'istesso modo li fù dato il magazeno sotto la casa grande pria obligato all'illu(strissi)mo, e r(everendissi)mo mons(igno)r testatore come il tutto consta tanto della Braida, quanto del magazeno nell'instrom(en)ti publici. Oltre diciò dichiara esso mons(igno)r ill(ustrissi)mo e r(everendi)ssimo ves(co)vo testatore per 
sgravio della sua conscienza che la vigna Dol sia la vera dote, e patrimonio della capella di S(an) Cosma, e Daminao, come confessa nel testamento della q(uonda)m sig(nor)a ved(ov)a Fran(ces)ca Zaur, onde detta vigna doverà sempre conservarsi libera, ne da alcuno potra venderse ne in alcun modo usurparsi, essendo dote, e fondazione di sud(et)ta capella delli Santi Martiri Cosma, e Damiano. E questo dice l'ill(ustrissi)mo, e r(everendi)ssimo mons(igno)r ves(co)vo testatore essere sua ultima volontà, la quale vuol voglia per ragione di testam(en)to o' se p(er) testam(en)to valer non potesse, voglia per ragion di codicillo, e se per ragione di codicillo voler non potesse voglia, e voler debba per ragione di donazione causa mortis vel ad pias causas, overo per ragione di qualunque altra ultima volontà, ò qual sivoglia altra ragione, o sia lascito ad causas pias etc.

\section{(12)}

Nominando, ed instituendo per suoi commissarij o sia essecutori testamentarij l’ill(ustrissi)mo sig(no)r Gio(vanni) Giuseppe de Marburg di sua m(ae)stà ces(are)a consigliere, e capit(an)o del Contado di Pisino, ed il m(ol)to ill(ust)re, e r(everendi)ssimo sig(no)r can(oni)co Giuseppe Tudorovich, pregandoli voler assistere con tutto spirito $\mathrm{p}(\mathrm{er})$ metter in esecuzione questa sua ultima disposizione, [et volonta(!)], dovendo detto l'ill(sutrisssi)mo s(igno)r Gio(vanni) Giuseppe de Marburg nipote dell'ill(ustrissi)mo, e r(everendissi)mo mons(igno)r testatore essere riconosciuto dalla sua sig(no)ra erede con un bacil, e brocha d'argento $\mathrm{p}(\mathrm{er})$ puro affetto, che sempre l'hà portato sud(et)to ill(ustrissi)mo, e r(everendi)ssimo mon(igno)r testatore suo zio: pregando me infra(scrit)to pub(li)co imp(eria)le notaro di publicar alla presenza delli sottos(cri)ti testimonij il presente suo ultimo nuncupativo testamento, si e come feci, che tanto etc etc, et omni meliori modo, via, ratione, et forma etc. L. S. Pietro Ant(oni)o Gaus ves(co)vo di Pedena etc. affermo quanto di sopra mp. Gio(vanni) Battista de Jacometis can(oni)co e vic(ari)o g(enera)le fui pres(en)te $\mathrm{p}(\mathrm{er})$ testimonio mp.

Simone Sancovich can(oni)co fui pres(en)te p(er) testimone mp Can(oni)co Giacomo de Viccho fui pres(en)te p(er) testimone mp Can(oni)co Santo Hainoga fui pres(en)te p(er) testimone mp Io $\mathrm{P}$ (ater) Stefano Marcovich fui pres(en)te testimonio mp Io sudiacono Simone Bellazzi fui pres(en)te testimonio mp Io Ant(oni))o Braissa uno de giudici fui pres(en)te testimonio mp 
Io Gioanni Tesach di Giorgio fui pres(en)te testimonio mp

L. S. Cristoforo Hainoga p(er) la sac(r)a imp(eria)le autorità not(ar)o pub(lic)o ricercato dall'ill(ustrissi)mo, e r(everendi)ssimo mons(igno)r ves(co)vo testatore sud(et)to il presente testam(en)to fedelm(en)te scrisse mp.

\section{Prilog 2.: Kodicil}

\section{Seque il codicillo}

\section{(A)}

Nel Nome di Gesu Cristo Salvatore. Nell'anno corr(en)te della sua S(antissi)ma Natività 1716 indizione 9a giorno di lunedi li 20 del mese aprile fatta in Pedena nel palazzo episcopale nella camera chiamata Stuva alla presenza delli testimonij à quest'avuti chiamati, e specialme(en)te pregati, cioè il r(everedi)ssimo sig(no)r Gio(vanni) Batt(is)a de Jacometis vicario g(enera)le, e canonico di questa cattedrale. [Mon(signor)] sig(no)r Giacomo de Viccho can(oni)co. [Mon(signor)] sig(no)r d(on) Santo Hainoga can(oni)co et r(everen)do diacono Simone Bellazzi, et s(igno)r r(everend)o Mattio Ifsich suddiacono. Tutti di questa città.

L'il(ustrissi)mo, e r(everedi)ssimo mons(igno)r Pietro Antonio Gaus de Omperg, abate di S(an) Giorgio in Canat della sacros(an)ta teologia d(otto)re, di sua ces(are)a catt(oli)ca maestà consigliere, sig(no)re di Gollagorizza, e ves(co)vo di questa città etc. Nella camara sudetta giacendo nel suo letto per grazia del Sig(no)re Iddio sano di mente, sensi, memoria, loquella, udito, ed intelletto, benche infermo del corpo, col pres(en)te codicillo hà voluto ultimam(en)te disponere de suoi beni, ed effetti. Et avendo sua sig(no)ria ill(ustrissi)ma e r(everendi)ssima fatto un testamento nuncupativo per mano di me notaro sottoscritto, e perche circa alcune cose in detto testamento contenute hà mutato volontà:

Prima col pres(en)te codicillo hà ordinato, e comandato, che il pred(et)to testamento haver debba pienissima

\section{(B)}

forza, e vigore, questo però mutato, che li fiorini cento cragnolini che in detto testamento hà lasciato $\mathrm{p}(\mathrm{er})$ legato al sig(no)r Giuseppe Gaus suo dilet- 
tissimo nipote non gli debbano darsi, avendo sua sig(nori)a ill(ustrissi)ma e r(evredi)ssima fatto una obligazione p(er) esso s(igno)r Giuseppe Gaus alli molto r(everendi) p(adri) della vene(ra)bile religione Paulina del convento di S(an) Pietro di Selve di darli quella summa, che contiene detta obligazione, mentre farà professione nella detta religione Paulina, altrim(en)te ne quella debba darsegli.

Item il baule con la sua brocha d'argento, che aveva lasciato per legato all'ill(ustrissi)mo sig(no)r Gio(vanni) Giuseppe de Marburg suo nipote, col pres(en)te codicillo gl'hà levato tal legato, lasciandoli in loco di detto una taza d'argento indorata.

Item le due milla messe basse che in detto testamento hà lasciato $\mathrm{p}(\mathrm{er})$ suffraggio dell'anima sua, ordina sua sig(nor)ia ill(ustrissi)ma, e r(everendi)ssima siano celebrate prontamente dalli mons(igno)ri capitolari, e religiosi in questa città messe mille e dalli mons(igno)ri canonici, e religiosi di Fiume altre messe mille più presto sarà possibile.

Item sua sig(nori)a ill(ustrissi)ma, e r(everendi)ssima lascia, e lega due milla messe basse pro pluribus defunctis, sia pagata cadauna messa con lira una secondo il solito del paese. Item messe basse p(er) l'anima d'un sacerdote n(umer)o 500: e per l'anima d'un laico altre messe basse n(umer)o 500.

Item al m(ol)to ill(ust)re sig(no)r Pietro Tudorovich suo dilettissimo nipote sua sig(nori)a ill(ustrissi)ma, e r(everendi)ssima lascia, e lega il baule con la brocha d'argento grande $\mathrm{p}(\mathrm{er})$ vero affetto, ed all'ecc(elentissi)mo sig(no)r $\mathrm{d}($ otto)re Saverio Gaus suo dilettissimo nipote

\section{(C)}

lascia, e lega il baule piccolo con la brocha d'argento olem p(er) puro affetto. Item lascia, e lega per una volta tantum al m(on)s(ignor) canonico Giacomo de Viccho ducati cinquanta di lire sei il ducato, acciò sia memore dell'anima di sua sig(nori)a ill(ustrissi)ma, e r(everendi)ssima.

Item lascia, e lega al s(igno)r chierico Antonio Clai ducati venti di lire sei l’uno $\mathrm{p}(\mathrm{er})$ affetto della fedele servitù prestata à sua sig(nori)a ill(ustrissi)ma, e r(everendi)ssima, pro una vice tantum, ed al Mattio Bellaz sacristano lascia ducati sei di lire sei l'uno. La m(olt)o ill(ust)re signora Vitoria Tudorovich sua dilettissima sorella, ed erede dovrà sodisfare à cadauno di quanto contiene legati suddetti, e pres(en)te codicillo specificati.

Item sua sig(nori)a ill(ustri)ssima, e r(everendi)ssima lascia, e lega alla scuola 
di S(an) Antonio di Padova di Fiume per pura divozione per una volta tantum ducati cento di lire sei il Ducato.

Item lascia, e lega siano vestiti n(umer)o 12 poveri mendici di griso agnellino prefano, acciò preghino Iddio per suffraggio dell'anima di sua sig(nori)a ill(ustrissi)ma e r(everendi)ssima. E quest'hà detto sua sig(nori)a ill(ustrissi)ma, e r(everendi)ssima voler, che sia la sua ultima volontà, la quale hà voluto che vaglia per ragion di codicillo, esser qualsisia altra ragione, che meglio valer possi etc. cosi etc.

Gio(vanni) Batt(ist)a de Jacometis can(oni)co e vic(ari)o g(enera)le fui pres(en)te per testimone $\mathrm{m}(\mathrm{anu}) \mathrm{p}$ (ropria).

Giacomo de Viccho can(oni)co fui pres(en)te per testimone m(anu) p(ropria) Santo Hainoga can(oni)co fui pres(en)te per testimone m(anu) p(ropria)

(D)

Diacono Simone Bellazzi fui pres(en)te per testim(on)e m(anu) p(ropria)

Suddiacono Mattio Sffich fui pres(en)te per testimo(ne) m(anu) p(ropria) Cristoforo Hainoga suppano p(er) la sa(cr)a impe(ria)le autorità notaro publico ricercato da ill(ustrissi)mo, e r(everendi)ssimo mons(igno)r ves(co)vo Gaus sud(et)to il pres(en)te codicillo fedel(men)te scrisse m(anu) p(ropria).

Ed io Marco Bancich capellano della venerabile confraternità del Purgatorio in Pedena dal testamento originale, e codicillo, fidatomi dall'eredi q(uonda)m Cristoforo Hainoga, da parola in parola hò estratto la pres(en)te copia con fedeltà $\mathrm{m}(\mathrm{anu}) \mathrm{p}$ (ropria).

Die 19. Julij 1743. in Off(ici)o E(pisco)p(a)li Petenae etc.

Praesentes cum originalibus suis contuli, ${ }^{241}$ colationavi et quia concordare inveni in fidem me subscripsi etc. ego archip(resbite)r Josephus Ant(oni)us Costanza p(roto)not(ari)us ap(osto)licus, parochus in Cherbune, et cancel(a)rius Dioecesis Petinensis $\mathrm{m}(\mathrm{anu}) \mathrm{p}$ (ropria).

241 Autor ovjere, Costanza, ispravlja glagole iz 3. lica jednine u 1. lice jednine (contulit, colationavit). Zahvaljujem Mileni Joksimović na pruženim stručnim savjetima glede latinskoga dijela prijepisa. 
